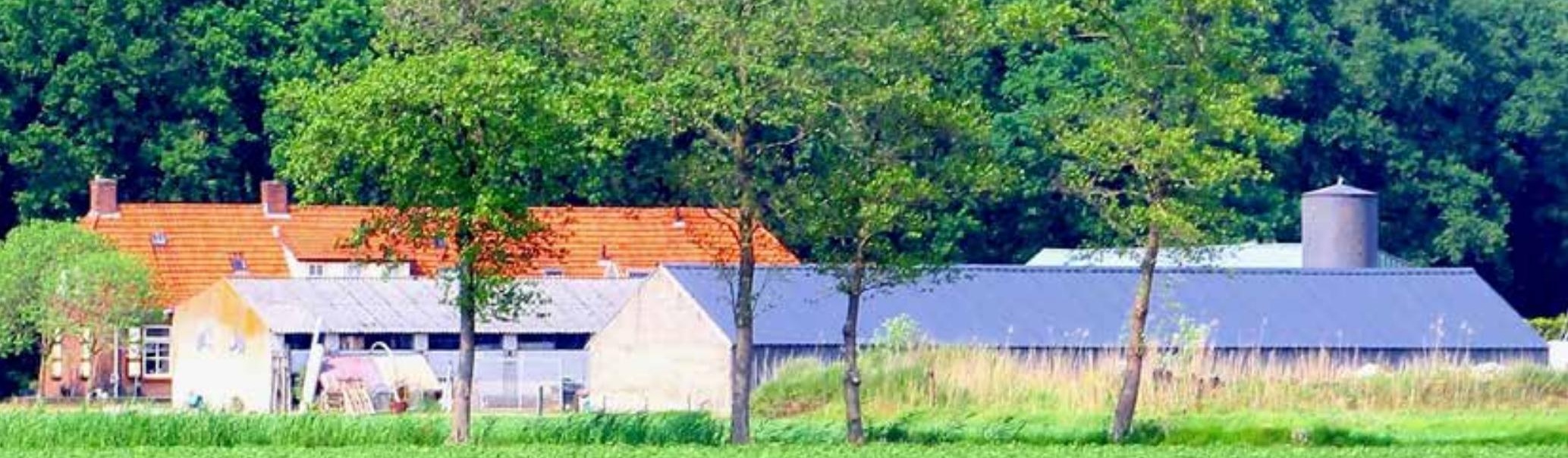

\title{
2.
}

-

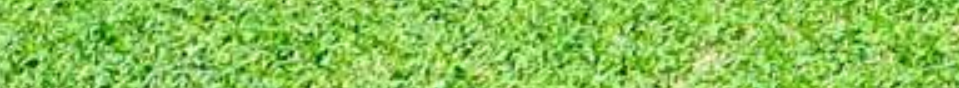

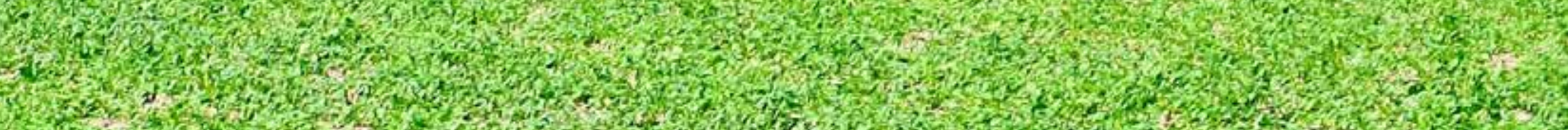

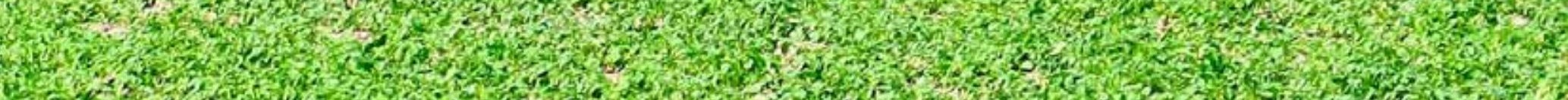

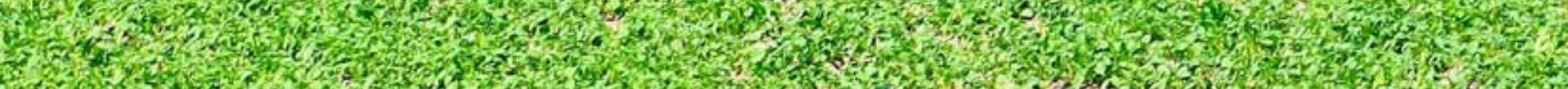

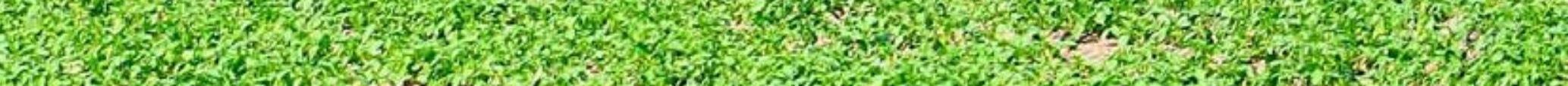

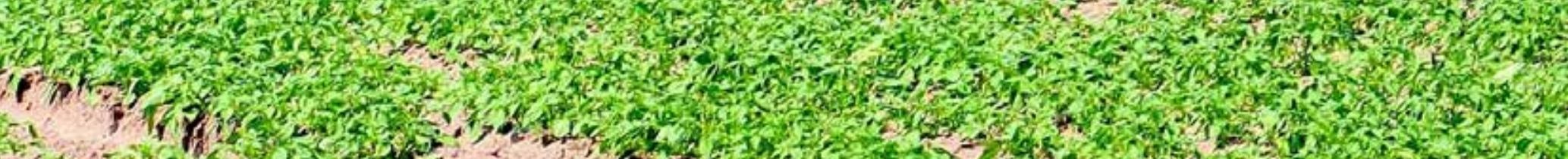
1.

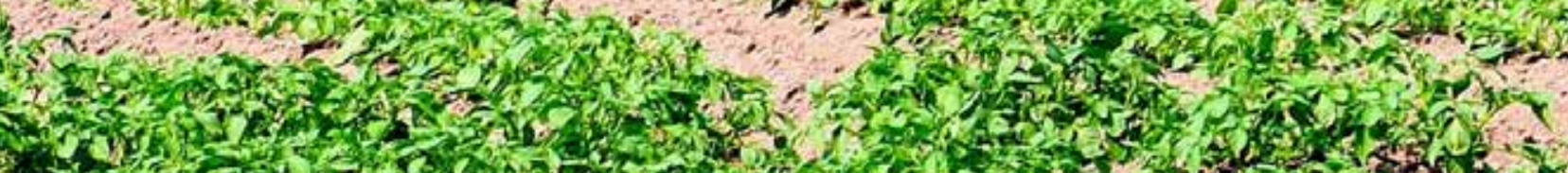

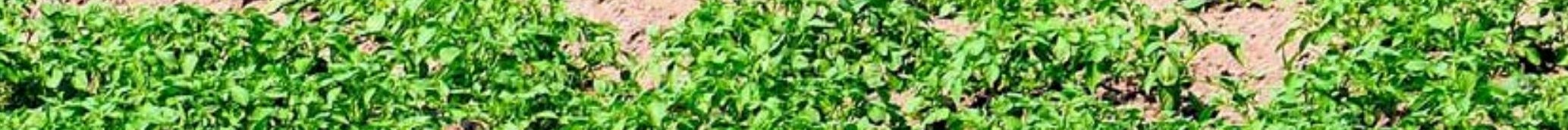

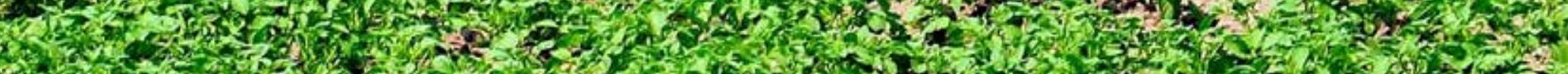

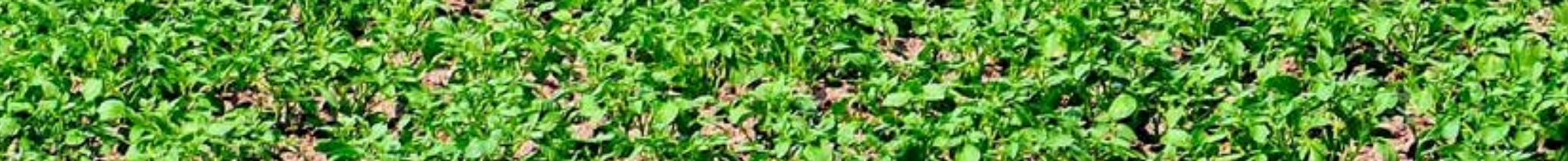

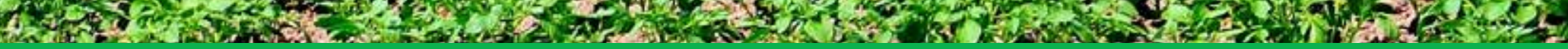

\section{Economic implications of ammonia regulation in the Netherlands near Natura 2000 areas}

Harry Luesink and Rolf Michels 



\section{Economic implications of ammonia regulation in the Netherlands near Natura 2000 areas}

Harry Luesink and Rolf Michels

This study was carried out by Wageningen Economic Research and was commissioned and financed by the University of Copenhagen.

Wageningen Economic Research

Wageningen, March 2018

REPORT

2018-010

ISBN 978-94-6343-845-2 
Luesink, H. And R. Michels, 2018. Economic implications of ammonia regulation in the Netherlands near Natura 2000 areas. Wageningen, Wageningen Economic Research, Report 2018-010. 44 pp.; 9 fig.; 12 tab.; 25 ref.

Ongeveer 900 landbouwbedrijven met dieren die binnen 2.000 meter van Natura 2000-gebieden liggen worden bij uitbreiding met extra kosten geconfronteerd. Op nationaal niveau worden die extra kosten jaarlijks geschat op € 9-13 miljoen. Voor de melkveehouderij worden de extra kosten jaarlijks geschat op $€ 5,7$ miljoen en voor vleesvarkensbedrijven op jaarlijks $€ 0,4$ miljoen.

About 900 farms with animals that are located within 2,000 m of a Natura 2000 area have to make extra costs when they expand. At the national level, the extra costs for these farms are estimated at about $€ 9-13$ million yearly. The extra costs for the dairy sector are estimated at $€ 5,7$ million per year and the extra costs for finisher farms at $€ 0.4$ million per year.

Key words: Economy, ammonia emission, Natura 2000

This report can be downloaded for free at https://doi.org/10.18174/444373 or at www.wur.eu/economic-research (under Wageningen Economic Research publications).

(C) 2018 Wageningen Economic Research

P.O. Box 29703, 2502 LS The Hague, The Netherlands, T +31 (0)70 3358330 ,

E communications.ssg@wur.nl, http://www.wur.eu/economic-research. Wageningen Economic Research is part of Wageningen University \& Research.

\section{(cc) BY-NC}

For its reports, Wageningen Economic Research utilises a Creative Commons Attributions 3.0 Netherlands license.

(C) Wageningen Economic Research, part of Stichting Wageningen Research, 2018

The user may reproduce, distribute and share this work and make derivative works from it. Material by third parties which is used in the work and which are subject to intellectual property rights may not be used without prior permission from the relevant third party. The user must attribute the work by stating the name indicated by the author or licensor but may not do this in such a way as to create the impression that the author/licensor endorses the use of the work or the work of the user. The user may not use the work for commercial purposes.

Wageningen Economic Research accepts no liability for any damage resulting from the use of the results of this study or the application of the advice contained in it.

Wageningen Economic Research is ISO 9001:2008 certified.

Wageningen Economic Research Report 2018-010 | Project code 2282200328

Cover photo: Shutterstock 


\section{Contents}

Summary $\quad 5$

S.1 Key findings $\quad 5$

S.2 Complementary findings $\quad 5$

S.3 Method 6

$\begin{array}{ll}\text { Samenvatting } & 7\end{array}$

$\begin{array}{lll}\text { S.1 Belangrijkste uitkomsten } & 7\end{array}$

$\begin{array}{lll}\text { S.2 Overige uitkomsten } & 7\end{array}$

$\begin{array}{lll}\text { S.3 Methode } & 8\end{array}$

1

$\begin{array}{ll}\text { Introduction } & 9\end{array}$

$\begin{array}{lll}1.1 & \text { Reference } & 9\end{array}$

1.2 Objective 9

$\begin{array}{lll}1.3 & \text { Approach and reading information } & 9\end{array}$

$2 \quad$ Data sources and method $r$

$\begin{array}{lll}2.1 & \text { Brief overview of agricultural production } & 10\end{array}$

$\begin{array}{lll}2.2 & \text { Overview of ammonia-reduction measures } & 10\end{array}$

$\begin{array}{ll}2.3 \text { Costs of ammonia-reduction measures at farm level } & 10\end{array}$

$\begin{array}{llr}3 & \text { Brief overview of agricultural production } & 11\end{array}$

$\begin{array}{lll}3.1 & \text { General } & 11\end{array}$

3.2 Export of livestock products $\quad 13$

$\begin{array}{lll}3.3 & \text { Agriculture production near Natura } 2000 \text { areas } & 13\end{array}$

4 Overview of ammonia reduction measures $\quad 16$

4.1 Regular ammonia emission regulation $\quad 16$

4.2 Integrated Approach to Nitrogen (PAS) 18

4.3 The principles of room for deposition and room for economic development 20

$\begin{array}{lll}4.4 & \text { Room for development for agriculture } & 21\end{array}$

$\begin{array}{lll}4.5 & \text { Calculations of nitrogen deposition impact } & 21\end{array}$

$\begin{array}{lll}4.6 & \text { Allocation of room for deposition } & 21\end{array}$

$\begin{array}{lll}4.7 & \text { Monitoring and adjustments } & 24\end{array}$

$\begin{array}{lll}4.8 & \text { Favourable conservation status and critical loads } & 24\end{array}$

$5 \quad$ Costs of ammonia-reduction measures $\quad 26$

5.1 General 26

$\begin{array}{lll}5.2 & \text { Finishers } & 26\end{array}$

$\begin{array}{lll}5.3 & \text { Dairy cows } & 28\end{array}$

$\begin{array}{lll}5.4 & \text { Broilers } & 29\end{array}$ 
Appendix 1 Characteristics of the cases and the case farms before expanding

Appendix 2 Overview Dutch agriculture near nature

Appendix 3 Emission factors from Dutch Regeling Ammoniak en Veehouderij (RAV) 


\title{
Summary
}

\section{S.1 Key findings}

\begin{abstract}
About 900 farms with animals and no room for development that are located within 2,000 m of a Natura $\mathbf{2 0 0 0}$ area have to make extra costs when they expand. At the national level, the extra costs for these farms are estimated at about c9-13 million yearly. All these costs are housing costs. The extra costs for the dairy sector are estimated at $\mathbf{C 5 . 7}$ million per year; the extra costs for finisher farms are $\mathbf{C} 0.4$ million per year and broiler farms have no extra costs.
\end{abstract}

In 2016, there were about 55,500 farms in the Netherlands, of which 16,500 were dairy farms, 1,600 finisher farms and almost 500 broiler farms. On these farms, 4.3 million cattle, including 1.8 million dairy cows, 12.5 million pigs and 105 million chickens were kept. Almost $30 \%$ of the agricultural area, $28 \%$ of the dairy cows, $18 \%$ of the finishers and $17 \%$ of the broilers in the Netherlands are located within 2,000 m of at least one Natura 2000 area. Finisher and broiler farms that are located near a Natura 2000 area are about 30\% smaller than the Dutch average.

The 1,800 farms that have an impact on nitrogen-sensitive Natura 2000 areas that want to expand may be confronted with two situations: for 900 farms there is either enough room for development for a nitrogen deposition up to $3 \mathrm{~mol}$ per hectare per year, or there is no room for development left. Room for development is the quantity of nitrogen deposition that is available for projects and activities that need a permit.

If room for development is available to the case farms, there are no extra costs involved when the farm is expanding (as long as the deposition on a Natura 2000 area does not exceed 3 mol per hectare per year). If no room for development is available at all, the farm has to make yearly extra costs of about $€ 20,000$ for finishers and almost $€ 16,000$ for dairy. This is because they have to build more expensive housing systems that reduce ammonia emissions. So finisher or dairy farms that have a significant negative influence on nitrogen-sensitive Natura 2000 habitats and want to expand their production, have to make higher costs than farms that have no negative influence.

\section{S.2 Complementary findings}

Whether a farmer close to a Natura 2000 area that wants to expand has to make extra costs compared to a farmer with no influence on a Natura 2000 area, depends on the actual impact that the farm has on nitrogen-sensitive Natura 2000 habitats in terms of nitrogen deposition, the availability of room for development and on the local and national rules that are in place.

Room for development is in principle made available to animal husbandry as a sector for a period of six years, as from 2015. It must be requested for all new activities that cause a nitrogen deposition on a nitrogen-sensitive habitat type of at least $1 \mathrm{~mol}$ per hectare per year. Sometimes, one activity can cause nitrogen deposition in several Natura 2000 areas at the same time. Room for development can be granted, if it is available and if the application complies with the provincial policies.

Room for development is made available at different moments in time. In principle, applications are processed in order of entry. Some provinces have determined that projects or activities must start within a specified period after licensing (within two years after the permit is granted in Overijssel).

The extra amount of ammonia emission that is allowed depends on the exact location of the farm with respect to the nitrogen-sensitive Natura 2000 area or areas (distance and main wind direction are important factors in that respect); the closer the farm is to a Natura 2000 area, the higher the nitrogen deposition is. 


\section{S.3 Method}

The University of Copenhagen requested Wageningen Economic Research to determine the impacts of measures to control ammonia emissions on animal production systems near Natura 2000 areas in the Netherlands. In more detail, the objective of the study is:

1. to gain insight into the measures that animal farms that are located near Natura 2000 areas have to take with respect to reducing ammonia emissions when they expand their animal production.

2. to assess the costs related to these measures.

3. to translate the economic aspects for the case farms to national level.

For the analysis, statistic data concerning the agricultural production, the ammonia-reduction measures and the cost of ammonia-reduction measures have been collected. This was done by Wageningen Economic Research and Wageningen Livestock Research.

The study starts with a brief overview of agricultural production. This is based on the national Agriculture census (CBS, 2017). The data on the national ammonia emission regulations are described as well.

The extra ammonia regulations for farms located near Natura 2000 areas have been analysed in detail. The costs of the ammonia-reducing measures that a farm has to take in case of expansion of their livestock in the proximity of Natura 2000 areas, are calculated for three case farms (see Appendix 1):

1. A farm with 7,200 finishers annually that is expanding to 14,400 produced finishers.

2. A farm with 120 dairy cows annually expanding to 240 dairy cows.

3. A farm with 300,000 broilers annually expanding to 600,000 produced broilers. 


\section{Samenvatting}

\section{S.1 Belangrijkste uitkomsten}

Ongeveer 900 landbouwbedrijven met dieren die binnen 2.000 meter van Natura 2000gebieden liggen worden bij uitbreiding met extra kosten geconfronteerd. Op nationaal niveau worden die extra kosten jaarlijks geschat op $€$ 9-13 miljoen. Voor de melkveehouderij worden de extra kosten jaarlijks geschat op $€ 5,7$ miljoen en voor vleesvarkensbedrijven op jaarlijks $€$ 0,4 miljoen.

In 2016 waren er in Nederland 55.000 landbouwbedrijven, waarvan 16,500 melkveebedrijven, 1.600 vleesvarkensbedrijven en 500 vleeskuikenbedrijven. Met op die landbouwbedrijven 4,3 miljoen runderen, waarvan 1,8 miljoen melkkoeien, 12,5 miljoen varkens en 105 miljoen stuks pluimvee. Bijna $30 \%$ van het landbouwareaal, $28 \%$ van het melkvee, $18 \%$ van de vleesvarkens en $17 \%$ van de vleeskuikens bevindt zich op bedrijven die gelegen zijn binnen 2.000 meter van een Natura 2000gebied. Vleesvarkens en vleeskuikenbedrijven die bij Natura 2000-gebieden liggen zijn ongeveer 30\% kleiner dan het Nederlandse gemiddelde.

Bedrijven die invloed hebben op stikstof-gevoelige Natura 2000-gebieden die willen uitbreiden worden geconfronteerd met twee situaties: er is genoeg ontwikkelingsruimte voor stikstof depositie van 3 mol per hectare per jaar of er is geen ontwikkelingsruimte. Ontwikkelingsruimte is de hoeveelheid stikstofdepositie die beschikbaar is voor projecten en activiteiten waarvoor toestemming is vereist.

Wanneer er ontwikkelingsruimte beschikbaar is voor de voorbeeldbedrijven, dan zijn er geen extra kosten wanneer het bedrijf uitbreidt, zolang de stikstofdepositie op een Natura 2000-gebied de 3 mol per ha niet overschrijdt. Wanneer er helemaal geen ontwikkelingsruimte beschikbaar is, dan dienen landbouwbedrijven jaarlijks extra kosten te maken van ongeveer $€ 20.000$ voor vleesvarkens- en $€ 16.000$ voor melkveebedrijven. Dat komt omdat ze duurdere huisvestingssystemen dienen te bouwen om de ammoniakemissie te reduceren. Dus vleesvarken- en melkveebedrijven die een significante negatieve invloed hebben op stikstofgevoelige Natura 2000-gebieden en die hun productie willen uitbreiden, hebben hogere kosten bij uitbreiding dan bedrijven zonder negatieve invloed.

\section{S.2 Overige uitkomsten}

Of een bedrijf dicht bij een Natura 2000-gebied dat wil uitbreiden meer kosten heeft in vergelijking met een bedrijf met geen invloed op een Natura 2000-gebied, hangt af van de actuele invloed dat het bedrijf heeft op stikstofgevoelige Natura 2000-gebieden in termen van stikstofdepositie, de beschikbaarheid van ontwikkelingsruimte en de lokale en nationale regelgeving die van toepassing is.

Ontwikkelingsruimte is vanaf 2015 in principe beschikbaar voor de veehouderij als sector voor een periode van zes jaar. Het is van toepassing voor alle nieuwe activiteiten die een stikstofdepositie tot gevolg hebben op stikstofgevoelige gebieden van minstens 1 mol per hectare per jaar. Soms kan een activiteit extra stikstofdepositie veroorzaken in meerdere Natura 2000-gebieden tegelijk.

Ontwikkelingsruimte kan worden gegarandeerd, als het beschikbaar is en de aanwending overeenstemt met de provinciale politiek.

Ontwikkelingsruimte is beschikbaar op verschillende momenten in de tijd. Aanvragen voor gebruik van ontwikkelingsruimte vinden plaats in volgorde van binnenkomst. Sommige provincies hebben vastgelegd dat projecten of activiteiten binnen een bepaalde periode na vergunningverlening dienen te starten (in Overijssel binnen twee jaar na de verlening van de vergunning). 
De extra hoeveelheid ammoniakemissie die is toegestaan hangt af van de exacte locatie van het bedrijf tot de stikstofgevoelige Natura 2000-gebied(en) (afstand en de overheersende windrichting zijn in die situatie belangrijke factoren). Hoe dichter het bedrijf bij een Natura 2000-gebied ligt, des te hoger de stikstofdepositie op dat gebied is.

\section{S.3 Methode}

De universiteit van Kopenhagen heeft Wageningen Economic Research gevraagd de invloed te onderzoeken van ammoniakemissiemaatregelen ten behoeve van bescherming van Natura 2000 gebieden op veehouderijbedrijven in Nederland wanneer ze uitbreiden. In meer detail is het doel van de studie:

1. het verkrijgen van inzicht in de maatregelen die veehouderijbedrijven bij Natura 2000-gebieden dienen te nemen ten aanzien van ammoniakemissie bij uitbreiding van hun veestapel.

2. het schatten van de kosten van die maatregelen.

3. het aggregeren van de economische aspecten van de voorbeeldbedrijven naar de nationale situatie.

Voor de analyse zijn statistische gegevens over de agrarische productie, maatregelen om de ammoniakemissie te reduceren en de kosten van die ammoniakemissiereductiemaatregelen verzameld. Het werk is uitgevoerd door Wageningen Economic Research en Wageningen Livestock Research.

De studie is gestart met het weergeven van een overzicht van de agrarische productie, die is gebaseerd op de landbouwtelling (CBS, 2017). Er wordt eveneens een overzicht en beschrijving gegeven van de nationale maatregelen van ammoniakemissie.

De extra ammoniakreductiemaatregelen die bedrijven bij Natura 2000-gebieden dienen te nemen zijn tot in detail geanalyseerd. De kosten van de ammoniakreductiemaatregelen die bedrijven in de nabijheid van Natura 2000-gebieden dienen te maken bij uitbreiding van hun veestapel zijn berekend voor drie voorbeeldbedrijven (zie bijlage 1 ):

1. een bedrijf met 7.200 vleesvarkens per jaar dat uitbreidt naar 14.400 vleesvarkens per jaar.

2. Een bedrijf met 120 melkkoeien dat uitbreidt naar 240 melkkoeien per jaar.

3. Een bedrijf met 300.000 vleeskuikens per jaar dat uitbreidt naar 600.000 vleeskuikens per jaar. 


\section{Introduction}

\section{$1.1 \quad$ Reference}

The University of Copenhagen requested Wageningen Economic Research to calculate the economic impacts of measures to control ammonia emissions on animal production systems near Natura 2000 areas in the Netherlands.

More specifically, the University of Copenhagen asked for:

1. A brief overview of agriculture production, including the use of agricultural land in the Netherlands, complemented with a short overview of agricultural production related to and located near Natura 2000 areas.

2. An overview of specific ammonia-reducing measures that animal production farms (i.e. finishers, dairy cows and broilers) have to take when they want to expand their production capacity in the Netherlands. An expansion of $100 \%$ of the production capacity is considered for holdings that are either within 400 metres or 2,000 metres of a Natura 2000 area.

3. An assessment of the accumulated costs of these measures in the Netherlands for the aforementioned case farms, including a discussion and conclusion of the results.

4. Upscaling of the economic aspects of the case farms to national level.

\subsection{Objective}

The objective is:

1. to gain insight into the measures that animal farms that are located near Natura 2000 areas have to take with respect to reducing ammonia emissions when they expand their animal production.

2. to assess the costs related to these measures.

3. to translate the economic aspects for the case farms to national level.

\subsection{Approach and reading information}

For the analysis, statistic data concerning the agricultural production, the ammonia-reduction measures and the cost of ammonia-reduction measures has been collected by Wageningen Economic Research and Wageningen Livestock Research.

Chapter 2 of this report describes the data and method. Chapter 3 provides a brief overview of the agriculture production in the Netherlands. Chapter 4 gives an overview of the ammonia-reduction measures. Chapter 5 presents the costs of ammonia-reduction measures at farm level. Chapter 6 describes the impact of the measures at the national level and Chapter 7 draws the conclusions. 


\section{Data sources and method}

\subsection{Brief overview of agricultural production}

For the analysis of a brief description of the agricultural production and the use of agricultural land in the Netherlands data of the National Agricultural Census are used (CBS, 2017). For the most relevant types of livestock production, the average farm size, number of farms per type and the export of agricultural products data have been collected.

Furthermore, the number of farms that are located in the proximity of Natura 2000 areas have been collected with GIS tools. Special attention is given to livestock production farms statistics, such as the number of farms, number of animals, farm size and farm type.

\subsection{Overview of ammonia-reduction measures}

The briefly described national ammonia emission regulations in the Netherlands are connected with the project of the university of Utrecht for Denmark (Backus, 2017). The extra ammonia regulations for farms located near Natura 2000 are gathered from the ammonia emission laws of the Dutch government and possible economic compensation is analysed by experts of Wageningen Livestock Research. In the Netherlands, provinces (regional government bodies) are responsible for the implementation of nature policies and the regulation of ammonia emission close to nature habitats. The implementation differs between provinces. The focus of this study will be on the province of Overijssel; this province is representative as far as husbandry and share of Natura 2000 areas are concerned.

\subsection{Costs of ammonia-reduction measures at farm level}

The costs of the ammonia-reduction measures that a farm has to take in case of expansion of their livestock farm in the proximity of Natura 2000 areas are calculated for three case farms chosen by the Ministry of Environment and Food of Denmark (Appendix 1):

1. A farm with 7,200 finishers annually that is expanding to 14,400 finishers

2. A farm with 120 dairy cows annually expanding to 240 dairy cows

3. A farm with 300,000 broilers annually expanding to 600,000 broilers.

Per farm four variants are distinguished based on two distance levels (400 and 2,000 metres) from a Natura 2000 area and two levels of room for increase of the ammonia deposition (see Section 4.1.3 for more information on room for ammonia deposition). In the Netherlands, the ammonia emission that is allowed taking into account Natura 2000 areas depends on the available room for ammonia deposition. The analysis will consider situations where enough ammonia deposition room is available for a farm to increase the livestock production and for situations where there is not enough ammonia deposition room to increase the livestock production.

The measures that the case farms have to take when they expand and are located outside the influence zones of Natura 2000 areas are described. The description is based on Van Bruggen et al. (2017, Emissies naar lucht uit de landbouw 2015).

Using a literature study of the Dutch ammonia emission laws, a brief description is given of the extra measures expanding case farms have to take when they are located within the influence of Natura 2000 areas. The extra costs for the case farms are calculated and compared with the costs of expanding case farms that are located outside the influence zones of Natura 2000 areas. 


\section{Brief overview of agricultural production}

\subsection{General}

Dutch farms are continuously scaling up. Consequently, the number of farms declined in six years by almost $25 \%$ to 55,681 farms in 2016 (Table 3.1 ). About $15 \%$ of them are part-time farms ( $<25,000$ SO). The utilised agricultural area in 2016 has decreased by $4 \%$ since 2010 and the number of animals is slightly higher, especially cattle.

In 2016, the utilised agricultural area in the Netherlands was almost $1.8 \mathrm{~m}$ ha, of which $1.0 \mathrm{~m}$ ha is grassland and $0.8 \mathrm{~m}$ ha is arable crops (Table 3.1). Seventy-one per cent of all the grassland is permanent.

In 2016 , the number of Dutch cattle amounted to $4.3 \mathrm{~m}$ animals, of which $1.8 \mathrm{~m}$ were dairy cows and $1.3 \mathrm{~m}$ were young dairy cattle. The remainder mainly consisted of veal calves. Other grazing animals that are kept in the Netherlands are sheep (784,000 in 2016) and goats (500,000 in 2016). The number of pigs in the Netherlands in 2016 was $12.5 \mathrm{~m}$, of which $5.7 \mathrm{~m}$ were finishers and $0.9 \mathrm{~m}$ were sows. The number of chickens in 2016 was $105.6 \mathrm{~m}: 46.2 \mathrm{~m}$ laying hens and $49.2 \mathrm{~m}$ broilers (Table 3.1). Farms with pigs and chickens are mainly concentrated in the sandy regions in the southern and eastern parts of the Netherlands. Cattle can be found anywhere in the Netherlands, except in the typical arable areas in the southwestern part of the Netherlands, the IJsselmeerpolders and the northeastern coastal zone. Figure 3.1 gives a picture of the livestock density in the Netherlands at municipality level. All municipalities with a level of more than 1 had to transport a part of the produced manure in their municipality to other regions. There are a few municipalities that had to transport more than $80 \%$ of the manure production to other areas.

Table 3.1 Number of farms, agricultural area and average number of agricultural animals per year in the Netherlands, 2010 and 2016

\begin{tabular}{lrr} 
Description & 2010 & 2016 \\
\hline Number of farms & 72,324 & 55,681 \\
\hline Total agricultural area (X 1,000 ha) & 1,872 & 1,796 \\
\hline - Grassland & 995 & 975 \\
\hline - Green feed crops & 238 & 216 \\
\hline - Arable crops & 542 & 504 \\
\hline - Horticulture & 97 & 101 \\
\hline & & \\
\hline Number of animals (X 1,000) & 3,975 & 4,251 \\
\hline Cattle total & 1,479 & 1,745 \\
\hline - Dairy cows & 1,225 & 1,317 \\
\hline - Young dairy cattle & 1,130 & 784 \\
\hline Sheep & 353 & 500 \\
\hline Goats & 12,255 & 12,479 \\
\hline Total pigs & 5,874 & 5,726 \\
\hline - Finishers & 983 & 931 \\
\hline - Sows & 101,248 & 105,620 \\
\hline Chickens total & 47,904 & 46,212 \\
\hline - Laying hens (incl. youngsters) & 44,748 & 49,188 \\
\hline - Broilers & 7,344 & 8,742 \\
\hline - Parents for broilers & & \\
\hline
\end{tabular}

Source: Dutch National Agricultural Census (CBS, 2017). 


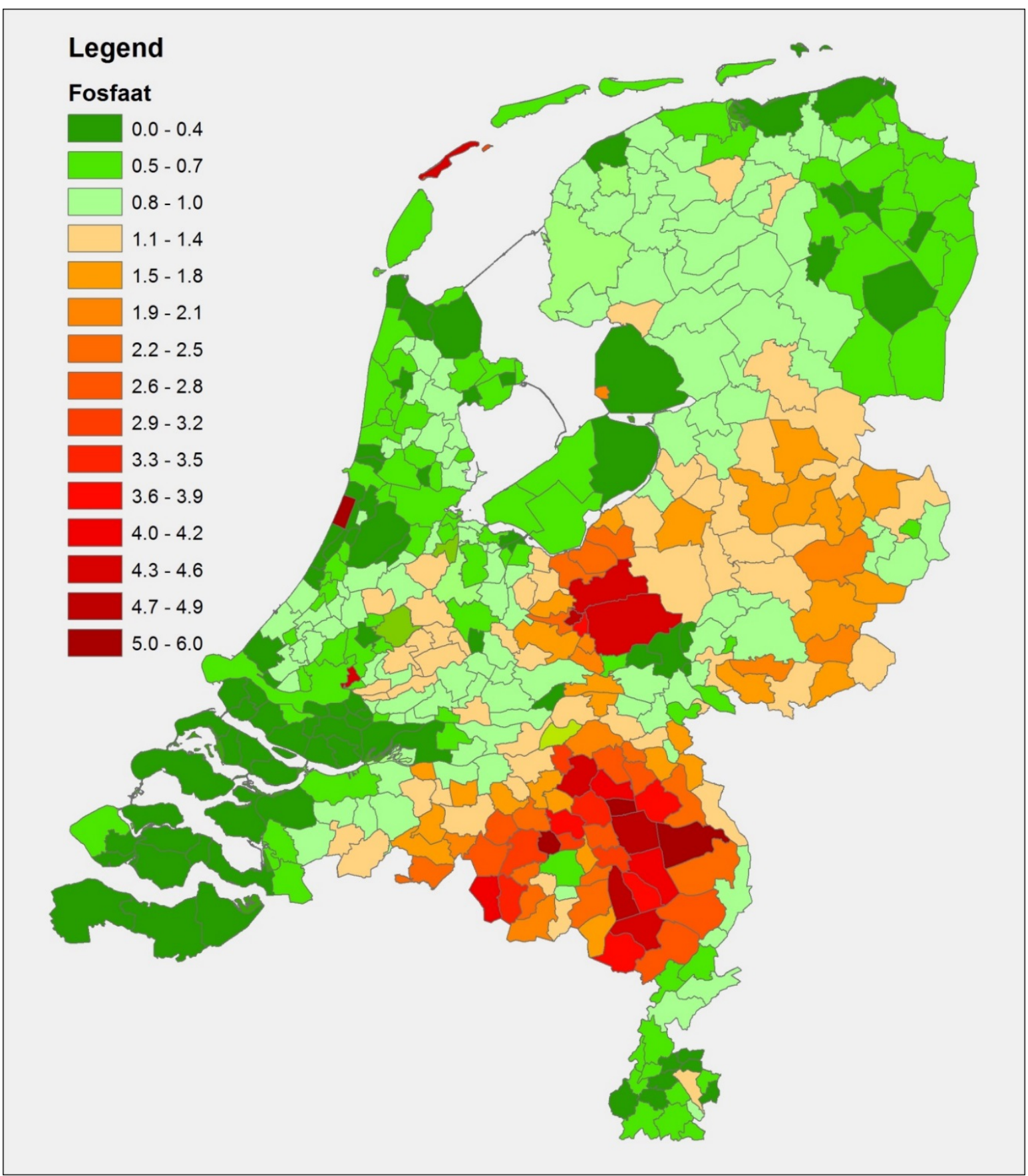

Figure 3.1 Phosphate production divided by the placing room for phosphate per municipality in 2012 (www.agrimatie.nl) a)

a) A level of 1 means production and placing room are in balance, whereas for instance a level of 2 means production is twice the amount that can be placed in the same municipality.

On average, the 16,500 dairy farms in 2016 used 52 ha of agricultural land and kept 101 milking cows (Table 3.2). In 2016, there were 1,600 finisher farms for pigs, 800 breeding farms for pigs and almost 700 closed pig farms (integrated production of sows and finishers) in the Netherlands. The farms for finishers generally are quite small, with almost 2,000 finishers per farm. The closed pig farms are bigger, with an average of 2,500 finishers and on average more than 400 sows. In 2016, the average laying hen farm had 65,000 laying hens and the average broiler farm had almost 100,000 broilers (Table 3.2). 
Table 3.2 Number of farms per farm type and the average size in utilised agriculture area and number of animals per farm in the Netherlands, in 2016

\begin{tabular}{|c|c|c|c|c|c|c|c|}
\hline Description & $\begin{array}{r}\text { Number of } \\
\text { farms }\end{array}$ & $\begin{array}{r}\text { Culture } \\
\text { area } \\
\text { (ha/farm) }\end{array}$ & $\begin{array}{r}\text { Dairy cows } \\
\text { (number/ } \\
\text { farm) }\end{array}$ & $\begin{array}{r}\text { Finishers } \\
\text { (number/ } \\
\text { farm) }\end{array}$ & $\begin{array}{r}\text { Sows } \\
\text { (number/ } \\
\text { farm) }\end{array}$ & $\begin{array}{r}\text { Laying hens } \\
\text { (number/ } \\
\text { farm) }\end{array}$ & $\begin{array}{r}\text { Broilers } \\
\text { (number/ } \\
\text { farm) }\end{array}$ \\
\hline Horticulture farms & 7,389 & 12 & & & & & \\
\hline Remaining culture farms & 1,612 & 14 & & & & & \\
\hline - Dairy farms & 16,503 & 52 & 101 & & & & \\
\hline Shed animal farms & 4,837 & 13 & & 1,062 & 185 & 8,946 & 9,339 \\
\hline - Finishers & 1,648 & 11 & & 1,942 & & & \\
\hline - Breeding farms & 806 & 12 & & 159 & 707 & & \\
\hline Crop combination farms & 1,076 & 45 & & & & & \\
\hline Cattle combination farms & 607 & 34 & 52 & 527 & 34 & 3,112 & 2,340 \\
\hline $\begin{array}{l}\text { All other combination } \\
\text { farms }\end{array}$ & 1,429 & 45 & 16 & 102 & 10 & 452 & 1,732 \\
\hline Total/average & 55,681 & 32 & 31 & 103 & 17 & 830 & 883 \\
\hline
\end{tabular}

Source: Dutch national Agricultural sensus (CBS,2017).

\subsection{Export of livestock products}

In 2015 , the Dutch livestock export value was almost $€ 16 \mathrm{bn}$ and was primarily (55\%) based on cattle products (Table 3.3). Pig-related products made up $20 \%$ of the export value.

Table 3.3 Export value of Dutch livestock products in 2015

\begin{tabular}{|c|c|c|}
\hline Product & Value in $\mathrm{Cm}$ & Share $(\%)$ \\
\hline Cheese & 3,108 & 20 \\
\hline Cattle meat and their meat products & 2,488 & 16 \\
\hline Living pigs & 833 & 5 \\
\hline Poultry meat and their meat products & 2,904 & 18 \\
\hline Total & 15,711 & 100 \\
\hline
\end{tabular}

\subsection{Agriculture production near Natura 2000 areas}

Natura 2000 is a network of protected nature areas in the EU. The areas preserve and protect habitat types and wild animals and plants that are rare, endangered or characteristic for EU countries. Natura 2000 sites cover habitat, bird-protection and Ramsar-sites and they have been designated in order to protect specific species and habitats. The basis for Natura 2000 is the EU Birds Directive and Habitats Directive. These Directives dictate EU Member States to preserve selected species and habitats. For the location of the Natura 2000 areas, see Figure 3.2. Only a small amount of the Dutch utilised agriculture area lies within $400 \mathrm{~m}$ of one or more Natura 2000 areas. The same accounts for the number of animals that is kept within the proximity of Natura 2000 (Figure 3.3 and Appendix 2). Almost $30 \%$ of the agricultural area, $28 \%$ of the dairy cows, $18 \%$ of the finishers and $17 \%$ of the broilers in the Netherlands are located within 2,000 m of at least one Natura 2000 area. 


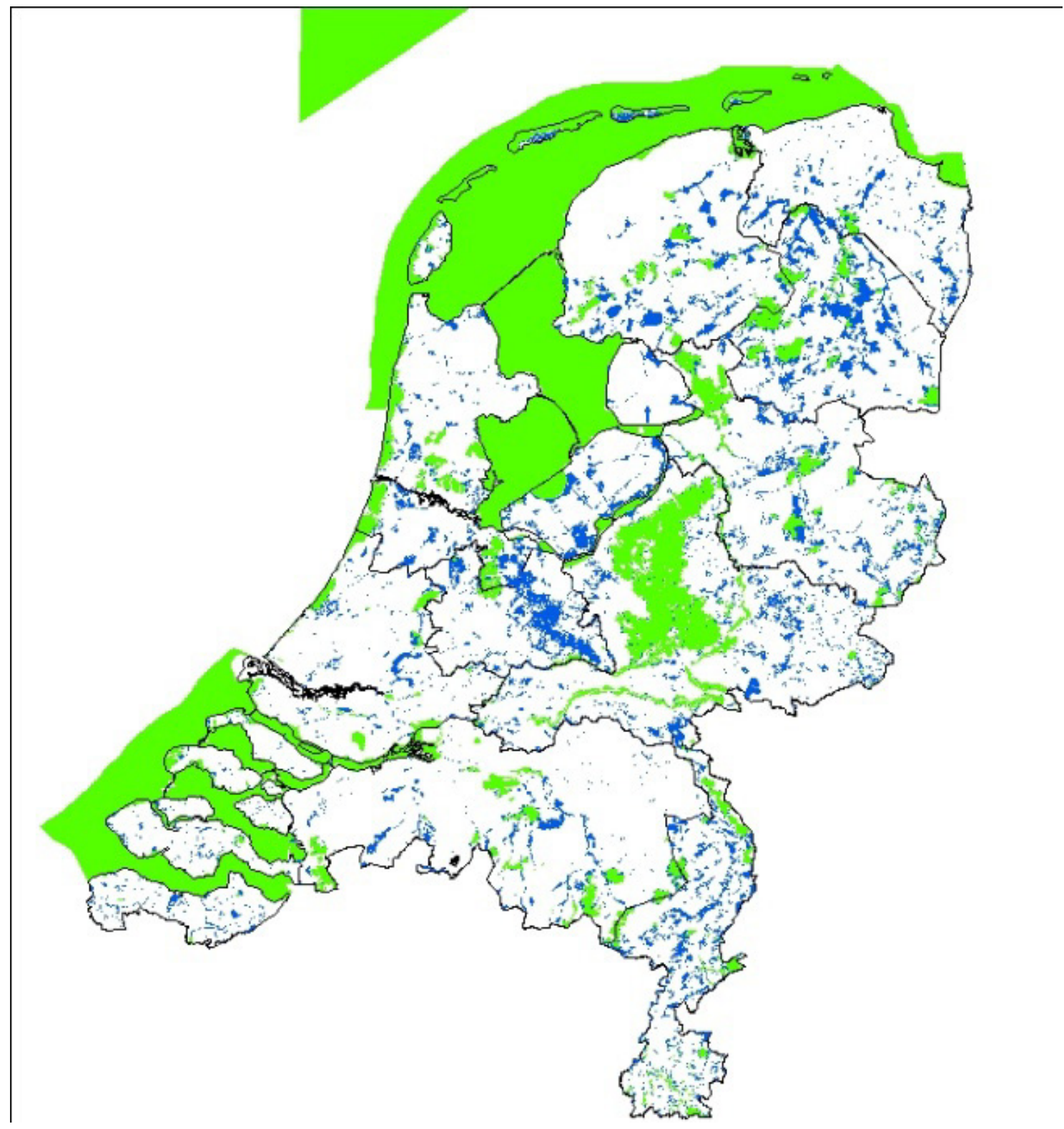

Figure 3.2 Location of Natura 2000 areas (green) and other nature (blue) in the Netherlands

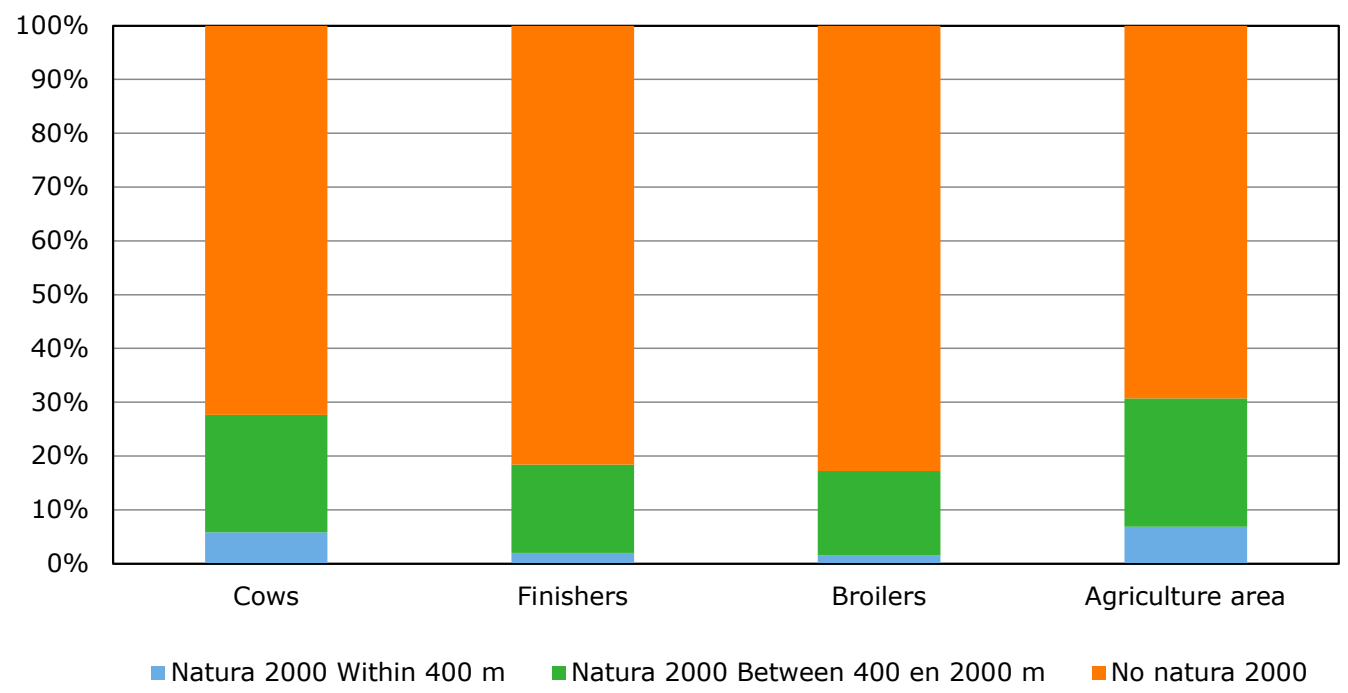

Figure 3.3 Agricultural area (\%) and amount of animals (\%) kept near Natura 2000 areas in the Netherlands, 2016

Source: Dutch National Agricultural Census (CBS, 2017), edited by Wageningen Economic Research. 
The number of farms per farm type and location (Figure 3.4 and Appendix 2) roughly has the same pattern as the number of animals. When it comes to finishers and broilers, a relative bigger part of the farms than of the animals is located near Natura 2000 areas. This is because farms located near nature are generally smaller than farms located further away from nature areas (see also Figure 3.5).

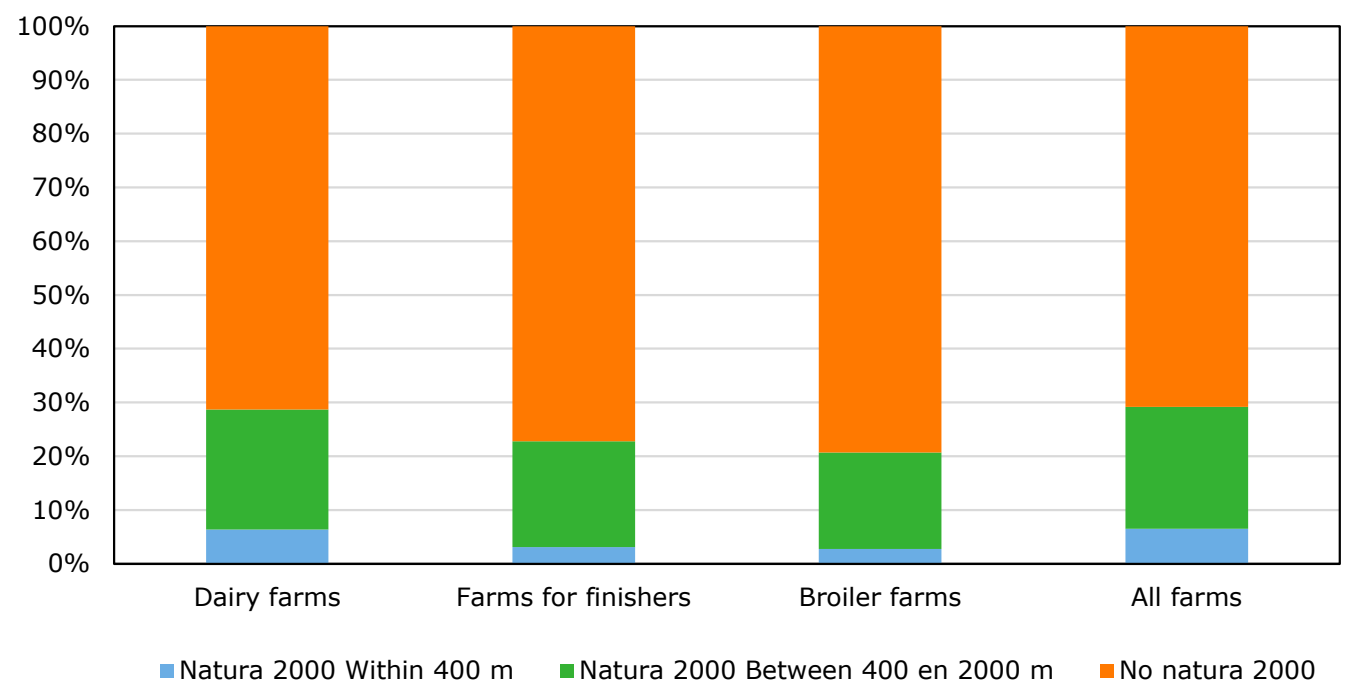

Figure 3.4 Number of farms (\%) per farm type and all farms located near Natura 2000 areas in the Netherlands, 2016

Source: Dutch National Agricultural Census (CBS, 2017), edited by Wageningen Economic Research.

Farms for finishers and broilers located at less than $400 \mathrm{~m}$ away from Natura 2000 areas have about half the number of animals than the Dutch average (Figure 3.5). Farms for finishers and broilers that are located within 400 and 2,000 m of Natura 2000 areas, are about $80 \%$ of the size of the Dutch average. For dairy farms, the size is almost similar regardless of the proximity of Natura 2000 areas.

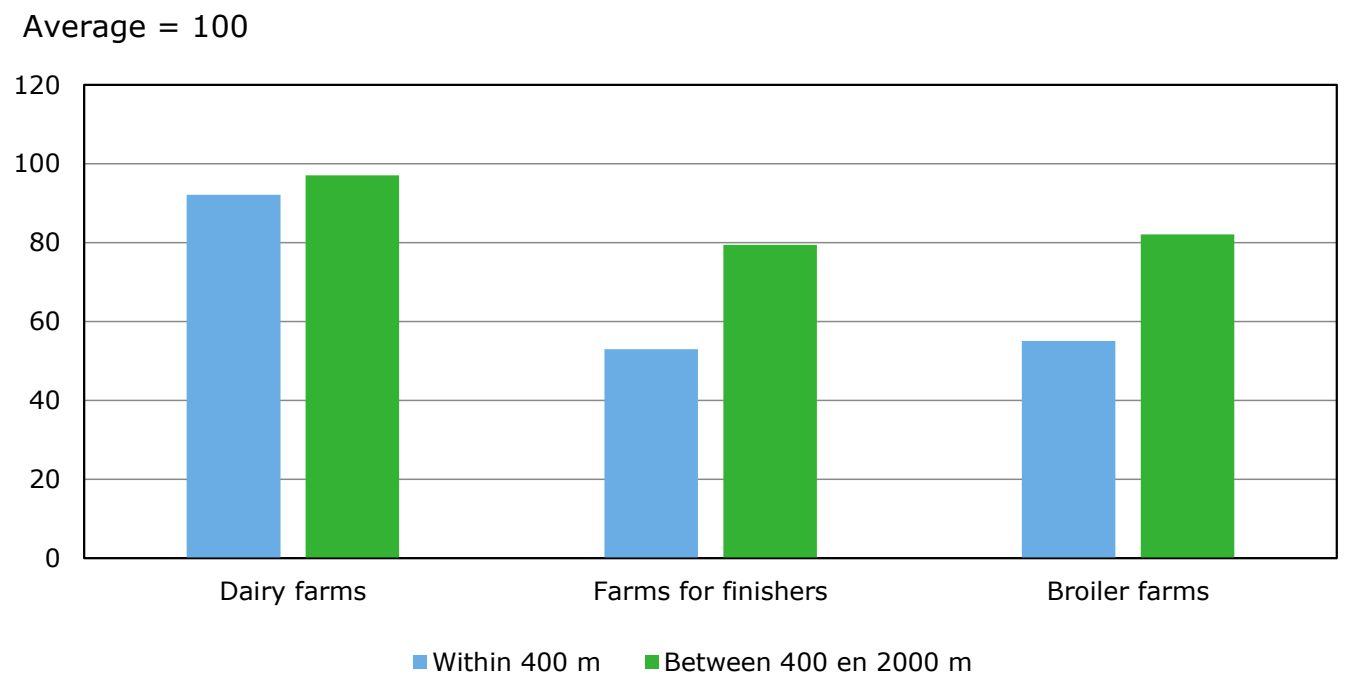

Figure 3.5 Farm size of farms for dairy, finishers and broilers near Natura 2000 areas (index: Dutch average $=100$ )

Source: Dutch National Agricultural Census (CBS, 2017), edited by Wageningen Economic Research. 


\section{Overview of ammonia reduction measures}

\subsection{Regular ammonia emission regulation}

For many years now, there has been a surplus of nitrogen (ammonia and nitrogen oxides) in Natura 2000 areas. This is harmful to nature and also hinders the issuing of permits for economic activities. Therefore, the Dutch Government has taken the initiative to address these nitrogen issues.

Manure application and storage

A ban on manure surface spreading came into force in 1991, making it mandatory to incorporate the manure into the soil either directly or shortly after application. To a large extent, this prevented the emission of ammonia $\left(\mathrm{NH}_{3}\right)$ after the application of animal manure.

Currently, in 2018, application of slurry on grassland is only allowed with:

- shallow injection

- sod injection

- narrow band application.

Application of slurry at arable land is only allowed with:

- injection

- shallow injection

- sod injection

- narrow band application

- incorporation in one track

Application of solid manure to arable land has to be incorporated in two tracks. Solid manure may still be applied to grassland with surface spreading, because there are no emission-poor techniques at grassland to do so.

Application of slurry to grassland is allowed from 16 February until 1 September. Application of solid manure is allowed from 1 February until 1 September on sandy and loss soils and on other soils until 16 September (RVO, 2017). On arable land, application of slurry is allowed from 1 February until 1 August and for solid manure on sandy and loss soils until 1 September. Application until 1 September is possible for slurry and solid manure when a green manure crop has been sowed. Application of solid manure to arable land at clay and peat soils is allowed the whole year round (RVO, 2017).

Also in the 1990s, it became mandatory to cover all manure storages.

\section{Animal housing}

More recently, the introduction of low emission housing for shed animals has been introduced. Since 2013, all farms with shed animals have to reduce the ammonia emission from stables. The emission factors for housing systems that farmers have to use are published in the RAV list (Regeling Ammoniak en Veehouderij, the Ammonia and Husbandry Regulation). Internal compensation is possible: this means that a part of a farmer's existing housing systems does not have to apply best available techniques (BAT), provided that the farmer compensates for the missed ammonia reduction by applying further techniques than BAT in other housing systems. Internal compensation can only be provided for housing systems in stables established before 1 January 2007. Also, farms that stop farming at 1 January 2020 at the latest may still keep animals in regular housing systems in the meantime. See Table 4.1 for the housing systems in 2015 of the most common animal categories in the Netherlands. 
For new housing systems, the allowed maximum ammonia emission is based on the best available techniques. This maximum may change every two or three years. Since 1 July 2015, new housing systems for the animals in the three cases must have ammonia emissions below the following values: ${ }^{1}$

Period: first of July 2015 till first of January 2018:

- Finishers: $1.5 \mathrm{~kg}$ of $\mathrm{NH}_{3}$ per animal place per year

- Dairy cows: $11.0 \mathrm{~kg}$ of $\mathrm{NH}_{3}$ per animal place per year

- Broilers: $0.035 \mathrm{~kg}$ of $\mathrm{NH}_{3}$ per animal place per year

Period before first of July 2015:

- Finishers: $1.6 \mathrm{~kg}$ of $\mathrm{NH}_{3}$ per animal place per year

- Dairy cows: $12.2 \mathrm{~kg}$ of $\mathrm{NH}_{3}$ per animal place per year

- Broilers: $0.045 \mathrm{~kg}$ of $\mathrm{NH}_{3}$ per animal place per year

Changes after 31 December 2017:

For dairy cows, the maxima will be stricter as of 1 January 2018:

- Dairy cows: $8.6 \mathrm{~kg}$ of $\mathrm{NH}_{3}$ per animal place per year

For finishers and broilers kept at IPPC farms, the maxima as of 1 January 2020 will be:

- Finishers: $1.1 \mathrm{~kg}$ of $\mathrm{NH}_{3}$ per animal place per year

- Broilers: $0.024 \mathrm{~kg}$ of $\mathrm{NH}_{3}$ per animal place per year

For this study, we take into account the allowed maxima for new stables from 2018:

- Finishers: $1.5 \mathrm{~kg}$ of $\mathrm{NH}_{3}$ per animal place per year

- Dairy cows: $8.6 \mathrm{~kg}$ of $\mathrm{NH}_{3}$ per animal place per year

- Broilers: $0.035 \mathrm{~kg}$ of $\mathrm{NH}_{3}$ per animal place per year 
Table 4.1 Housing systems in the Netherlands for the most common animal categories (\% of livestock) and ammonia emission per animal place, 2015

\begin{tabular}{|c|c|c|}
\hline Livestock category & $\%$ & $\mathrm{Kg}$ of $\mathrm{NH}_{3} /$ animal place \\
\hline \multicolumn{3}{|l|}{ Dairy cows } \\
\hline - regular housing & 81.3 & 13.0 \\
\hline - low emission cubicle or loose housing & 16.6 & $5.1-12.2$ a) \\
\hline \multicolumn{3}{|l|}{ Young dairy cattle } \\
\hline \multicolumn{3}{|l|}{ Pigs finishers } \\
\hline - regular housing & 26.9 & 3.0 \\
\hline - air scrubber & 46.1 & $0.15-0.9 a)$ \\
\hline - floor and/or manure pit adaptations & 27.0 & $1.0-2.4 \mathrm{a})$ \\
\hline - floor and/or manure pit adaptations & 28.5 & 2.4-5.0 a) \\
\hline \multicolumn{3}{|l|}{ Laying hens } \\
\hline - regular floor housing & 3.9 & 0.315 \\
\hline - low emission floor housing & 12.0 & $0.068-0.150 \mathrm{a})$ \\
\hline - regular aviary system & 27.6 & 0.09 \\
\hline - low emission aviary system & 37.9 & $0.025-0.055$ a) \\
\hline - enriched cage and group cage & 18.6 & 0.03 \\
\hline \multicolumn{3}{|l|}{ Broilers } \\
\hline - regular housing & 12.7 & 0.08 \\
\hline
\end{tabular}

a) Spreading of the possible systems; b) ammonia emission of maternity sows included piglets.

Source: Van Bruggen et al. (2017) and wetten.overheid.nl/BWBBR0013629/2017-04-12.

\section{Housing and location}

On top of the allowed ammonia emission per animal place for newly built or adjusted stables, there are also rules with respect to the location. According to the Ammonia and Animal Husbandry Law (Wet Ammoniak en Veehouderij, WAV), an environmental permit necessary for setting up a livestock farm shall be refused if an animal enclosure belonging to the livestock farm is wholly or partly located in a very vulnerable area, or within a $250-\mathrm{m}$ zone around such an area. Similarly, an environmental permit for changing a livestock farm shall be refused if the application relates to an increase in the number of animals in one or more animal categories and an animal accommodation belonging to the livestock sector is wholly or partly located in a very vulnerable area, or within a 250-m zone around such an area. Naturally, nitrogen-sensitive Natura 2000 habitats can be characterised as vulnerable areas.

\subsection{Integrated Approach to Nitrogen (PAS)}

Under the Integrated Approach to Nitrogen ('Programmatische Aanpak Stikstof', PAS), government authorities and social partners collaborate in order to reduce nitrogen emissions. The PAS will ensure that the objectives of European nature policy are being achieved, while creating the necessary room for economic development (De Heer et al., 2017).

For a densely populated country such as the Netherlands, it is quite a challenge to strike a balance between resilient nature and having a healthy economy. The national government and provincial authorities provide entrepreneurs with some room to manoeuvre, because they are important for the 
economy. At the same time, economic activities need to fit the carrying capacity of nature, as the economy and nature are in a mutually dependent relationship (Aerius, 2017). ${ }^{2}$

The conservation goal of the PAS is to avoid (further) deterioration of the conservation status of protected habitats in the short term (cf. Habitats Directive art. 6.2), and to contribute to achieving a favourable conservation status in the long term (cf. Habitats Directive art. 6.1). To achieve this goal, two types of measures are taken: generic source measures to reduce nitrogen emissions and ecological restoration measures in Natura 2000 areas (De Heer et al., 2017).

The source measures include implementation of the existing Dutch and European policies on nitrogen. These policies mainly focus on the sectors of agriculture, industry and traffic and transport, targeting emissions of both ammonia (NH3) and nitrogenoxides (NOx). Furthermore, especially for the PAS, an additional package with generic agricultural measures has been agreed with the agricultural sector (Ministry of Economic Affairs \& Ministry of Infrastructure and the Environment 2015a; Ministry of Economic Affairs, LTO, Netherlands, NZO, Nevedi, NMV, NVP, NVV and CUMELA Netherlands, 2014). This package involves measures on animal housing (e.g. air scrubbers), feed and management, and manure application techniques. These measures together should further reduce agricultural emissions, at least 10 ktonne by 2030, compared to the situation of 2013 (-9\%) (De Heer et al., 2017).

Ecological restoration within the framework of the PAS focuses on the 118 Natura 2000 areas in the Netherlands that contain nitrogen-sensitive habitats. These habitats are defined as habitats with a critical load of less than 2,400 mol/ha/year (34 kg N/ha/year). Most Dutch nature types are (very) nitrogen-sensitive: 37 nature types are very nitrogen-sensitive (a critical load of less than $1,400 \mathrm{~mol} / \mathrm{ha} /$ year or $20 \mathrm{~kg} \mathrm{~N} / \mathrm{ha} /$ year) and 44 nature types are nitrogen-sensitive (a critical load of 1,400 to $2,400 \mathrm{~mol} / \mathrm{ha} /$ year or 20 to $34 \mathrm{~kg} \mathrm{~N} / \mathrm{ha} /$ year). 17 nature types are not nitrogen-sensitive (a critical load of more than 2,400 mol/ha/year or $34 \mathrm{~kg} \mathrm{~N} / \mathrm{ha} /$ year) (Van Dobben, Bobbink, Bal and Van Hinsberg, 2014).

For nature areas in the Netherlands that do not contain nitrogen-sensitive habitats, high levels of nitrogen deposition are no problem. Restoration may involve measures to remove nitrogen from ecosystems, such as removing topsoil layers (sodding). It can also involve more generic measures to make ecosystems more resilient against the effects of nitrogen, such as hydrological measures. The PAS contains 69 restoration strategies, each containing a package of measures (Jansen, Van Dobben, Nijssen, Bouwman and Bal, 2014; Smits and Bal, 2014; Smits, Adams, Bal and Beije, 2014). For the authorities concerned, implementation of the measures is a statutory requirement (De Heer et al., 2017).

North-Brabant and Limburg, two provinces in the south of the Netherlands, hold many livestock farms, that are the primary regional source of nitrogen emissions. In some regions, the emissions are more than $100 \mathrm{~kg}$ of $\mathrm{NH}_{3} / \mathrm{ha}$ /year due to intensive animal husbandry (Van Zanten et al., 2016). Both provinces have stipulated that livestock farms that want to expand, must meet lower (stricter) nitrogen emission standards than what is required nationally. Furthermore, all provinces agreed upon setting provincial rules for the allocation of room for development, on top of the national rules. For example, rules regarding the deadline for a project to start after a permit/license is granted or the maximum percentage a farm/holding may expand. Additionally, provinces may set additional policy rules.

To ensure that agricultural emissions are reduced by at least 10 ktonne by 2030, Dutch government has established more stringent rules regarding the use of fertilizers ('Besluit gebruik meststoffen') and animal housing ('Besluit emissiearme huisvesting'). Moreover, the government has implemented several incentive arrangements to achieve this target. A stringent rule is that from 1 January 2018 it is not allowed anymore to applicate manure with a drag foot. In addition, the maximum ammonia emission from newly built stables will be stricter on 1 January 2018 and 1 January 2020 (see Section 4.1.1.).

2 https://www.aerius.nl/en/the-integrated-approach-to-nitrogen-and-aerius/the-integrated-approach-to-nitrogen 


\subsection{The principles of room for deposition and room for economic development}

Room for deposition is the quantity of nitrogen deposition that is available for economic growth. A considerable part of the room for deposition is reserved for projects and activities that need a permit; this is called room for development. The remainder of the room for deposition is reserved for projects and activities that are exempted from compulsory licensing: autonomous growth, such as a road traffic increase, and initiatives causing less than $1 \mathrm{~mol}$ nitrogen deposition per hectare per year $(0.014 \mathrm{~kg} \mathrm{~N} / \mathrm{ha})$ in PAS areas.

Through cleaner combustion engines, existing policies and supplementary agricultural policy regarding PAS, nitrogen deposition will continue to decline in the coming years. In addition, measures in PAS areas will make nature less vulnerable to nitrogen. This leads to room for deposition.

Room for deposition is established and allocated per PAS area at the hectare level, based on so-called site analyses. For a site analysis, the calculation instrument AERIUS is used to calculate the potential room for deposition based on the expected decrease in nitrogen deposition. Moreover, the ecological restoration measures to be taken are described in the analysis. It is important to stress that room for development is only available if one key prerequisite is met: the combination of a decrease in nitrogen deposition and the implementation of restoration measures must actually ensure that habitats will not deteriorate further, so that eventually nature goals are being achieved. Experienced ecologists have ruled for all 118 areas that the combination of nitrogen deposition decrease, restoration measures and regular nature conservation is expected not to jeopardise the nature objectives of the area. This means that the responsible administrators can make room for development available. Room for development is set for a period of six years.

The AERIUS calculation tool is one of the cornerstones of the PAS. It calculates the level of nitrogen deposition in Natura 2000 areas, caused by projects and development plans. AERIUS supports the issuing of permits for economic activities that involve the emission of nitrogen, and monitors whether the total nitrogen burden continues to decline. In addition, AERIUS also facilitates spatial planning in relation to nitrogen. AERIUS is used for calculations for all nitrogen-sensitive Natura 2000 areas and all nitrogen-emitting sectors (agriculture, industry, and traffic \& transport) (Aerius, 2017). ${ }^{3}$

AERIUS calculates which part of the total room for deposition should be reserved for autonomous growth and for initiatives with limited nitrogen deposition. The remaining room for deposition is the available room for development for all projects and activities with a permit obligation. The PAS provides sufficient room for development for economic growth of $2.5 \%$ per year, taking into account differences in expected growth between sectors and regions. Based on recent economic growth figures, the growth is actually expected to be lower. If there is no room for development in a certain area, permits can no longer be issued for activities that cause nitrogen deposition in that area. Incidentally, additional room for deposition can be created by implementing additional source measures.

Room for development must be requested for all new activities that cause a nitrogen deposition on a nitrogen-sensitive habitat type of at least $1 \mathrm{~mol}$ per hectare per year. Sometimes, one activity can cause nitrogen deposition in several Natura 2000 areas at the same time. Room for development can be granted, if it is available and if the application complies with the provincial policies.

Room for development is made available at different moments in time. In principle, applications are processed in order of entry. Some provinces have determined that projects or activities must start within a specified period after licensing. It is not possible to issue more room for development than there is available.

3 https://www.aerius.nl/en/the-integrated-approach-to-nitrogen-and-aerius 


\subsection{Room for development for agriculture}

In the Agreement on Generic Measures in Agriculture ('Overeenkomst generieke maatregelen landbouw'), agreements are made to achieve an additional net decrease of nitrogen emissions in 2030 of 10 ktonne of ammonia compared to 2013 (reference date is 1 January 2014) (see Ministry of Economic Affairs et al., 2014). To establish this decrease in nitrogen emissions, both stable, feed and management measures are taken. Stable measures include air scrubbers, partially slatted floors, heaters and other ways to dry manure. Feed and management measures include decreasing the urea content of milk, promoting pasture grazing, reducing the protein content of the animal feed, and using air-filled balls as a floating cover for manure storage facilities. It has been agreed that, on average, $56 \%$ of the decrease in the 10 ktonne of ammonia emissions will be made available to animal husbandry again in the form of room for development.

\subsection{Calculations of nitrogen deposition impact}

The calculations of the impact of nitrogen deposition are illustrated by an example. Take a dairy farm with 220 dairy cows, 4 meat calves and 180 young cattle. The dairy cows, the meat calves and the young cattle are all housed in conventional stables. This farm has an ammonia emission of 3,666 $\mathrm{kg}$ of $\mathrm{NH}_{3}$ per year. The online calculation tool Aerius calculates the nitrogen deposition of this farm based on the weight, height and heat content of the ammonia emission, and the distance from the source (Aerius, 2017). In this example, the nitrogen deposition at $1 \mathrm{~km}$ of the farm will be $26 \mathrm{~mol} / \mathrm{ha} / \mathrm{year}$ $(0.4 \mathrm{~kg} \mathrm{~N} / \mathrm{ha})$. At $8 \mathrm{~km}$, the nitrogen deposition will be $1 \mathrm{~mol} / \mathrm{ha} / \mathrm{year}$. Note that this calculation is made in Aerius, based on a set of (default) values and assumptions. In practice, results may vary.

Aerius determines the impact of a project, for example farm expansion, on all nature areas. Obviously, only the impacts on nitrogen-sensitive Natura 2000 areas are relevant, for other nature areas are not affected by (high levels of) nitrogen. Aerius calculates the nitrogen deposition per hectare for all relevant nature hectares and gives the following output on the scale of the nature area (Aerius, 2017):

- What is the highest nitrogen deposition (mol/ha/year)?

- Does this deposition exceed the critical load (nitrogen-sensitive habitats have a critical load of less than 2,400 mol/ha/year or $34 \mathrm{~kg} \mathrm{~N} / \mathrm{ha} /$ year)?

- What is the highest required room for development (mol/ha/year)?

- Is this room for development available?

\subsection{Allocation of room for deposition}

The room for deposition is all room available for economic development, i.e. projects or activities that emit nitrogen. The room for deposition is set for a period of six years. One can distinguish between projects and actions that are not subject to permission and projects that require a permit (Figure 4.1). The first category consists of autonomous developments, such as an increase of population or road traffic, and from projects that cause less than a limit value in a Natura 2000 area. This limit value is set to reduce the burden for entrepreneurs as much as possible (PAS, 2017). So if the deposition that is expected to result from a new or expanded economic activity will be lower than the limit value, a permit is not required and the initiator only needs to notify the competent authorities (Ministry of Economic Affairs, 2015a). The limit value is basically $1 \mathrm{~mol} / \mathrm{ha} / \mathrm{year}$, but will be lowered to $0.05 \mathrm{~mol} / \mathrm{ha} /$ year after $95 \%$ of the reservation for the notifications is used. At the moment, many of the nitrogen sensitive nature areas have a limit value of $0.05 \mathrm{~mol} / \mathrm{ha} / \mathrm{year}$ (Figure 4.2 ). The second category of activities is divided into priority projects (segment 1, Figure 4.1) and other projects and operations (segment 2, Figure 4.1). Priority projects have been identified by the government or the provinces as projects of national or provincial social importance. The distribution of the room for deposition over the four parts is an administrative choice of the State and provinces (PAS, 2017). 


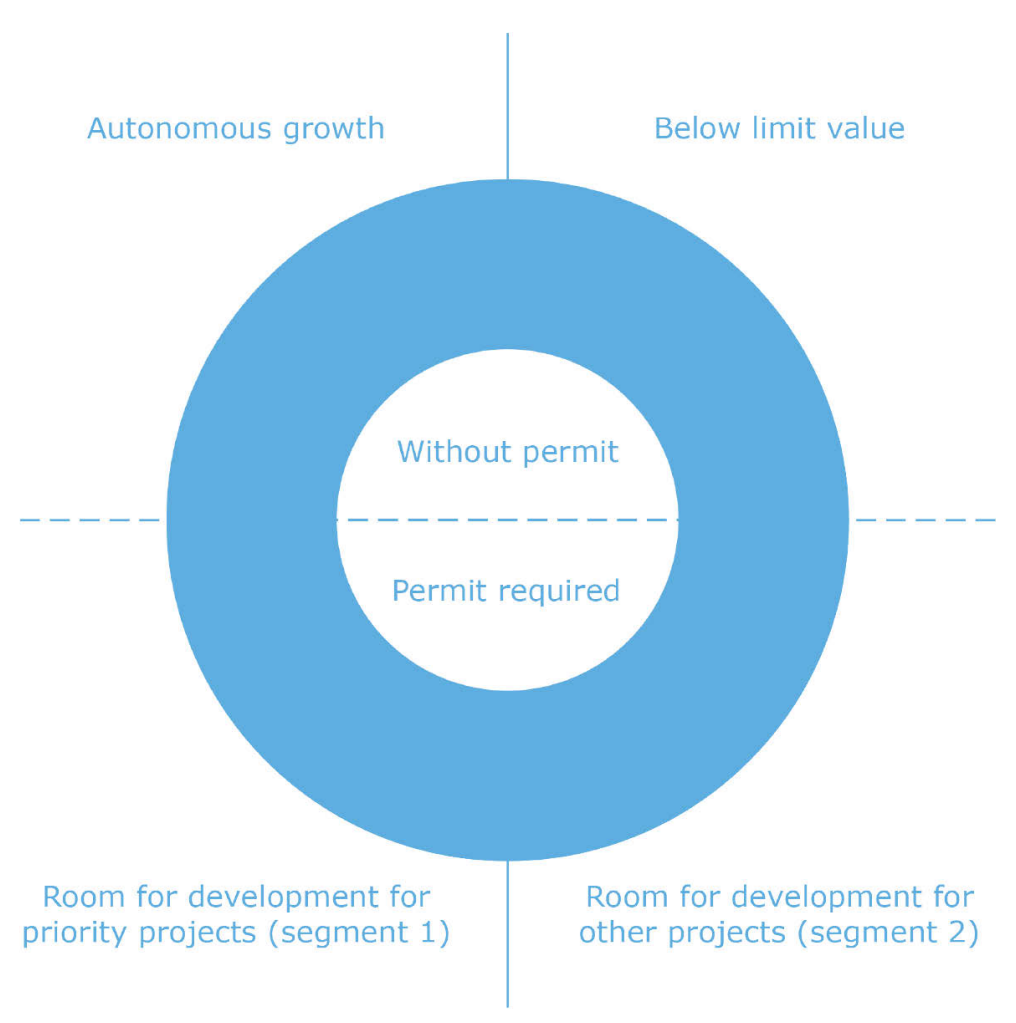

Figure 4.1 Allocation of room for deposition Source: Based on PAS (2017).

The twelve Dutch provinces are responsible for rule-making regarding the allocation of room for development. Provided that there is enough room for development available, a permit may be issued for projects and operations that fall into segment 2 (Figure 4.1, other projects). In Overijssel, the following policy rules apply (Provincie Overijssel, 2015):

- the additional deposition from the project does not exceed the maximum of $3 \mathrm{~mol} / \mathrm{ha} / \mathrm{year}$

- if the permit is issued, the project must be realised within two years after it has been granted

- first come, first serve; in other words, the order of receipt of a complete and acceptable application is valid (when arriving by mail, validity time is noon)

At the moment, enough room for development is available in Overijssel to issue permits for projects that fall into segment 2. In some regions in the Netherlands, for example in the province of Friesland, all room for development has already been issued and new applications are not accepted in the coming years. Please note that farmers in Overijssel could also have an impact on nitrogen-sensitive Natura 2000 areas in Friesland, which means that farms in Overijssel also could be hindered when they cause too much deposition in nature areas which are located in the province Friesland. This means that these farms in Overijssel might not be able to obtain room for development as well. 


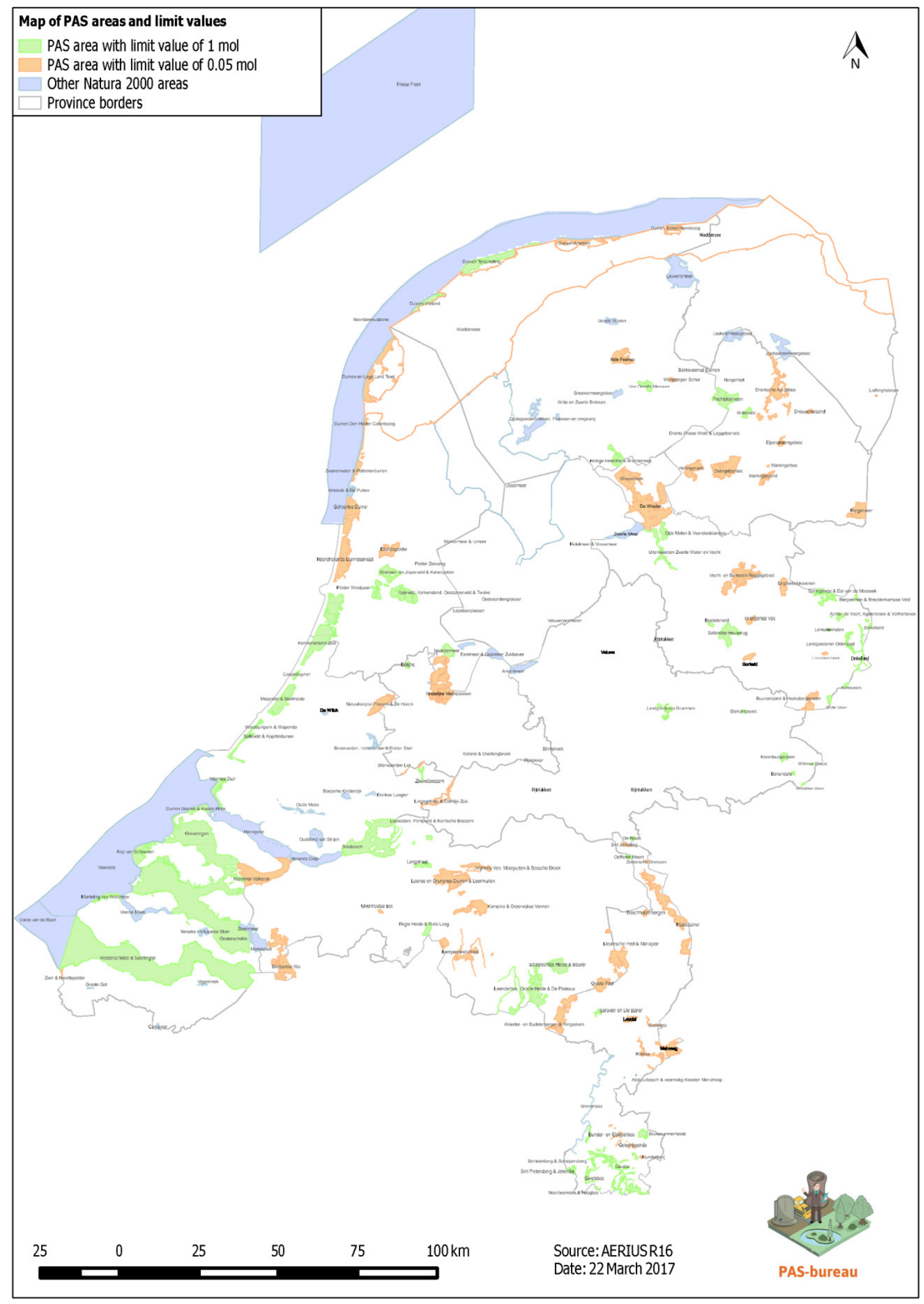

Figure 4.2 Map of PAS-areas and limit values 


\subsection{Monitoring and adjustments}

So what happens if it turns out that the deposition has not been reduced sufficiently and/or that nature has deteriorated? If the results of the monitoring programs show that the deposition reduction is lagging behind expectations or if nature quality improves insufficiently, adjustments may be considered. If nature is deteriorating, at first the cause for this deterioration will be investigated. If the cause has to do with the level of nitrogen deposition or the effectiveness of recovery measures, adjustments are due. Adjustments can be, for example, modifying, replacing or adding recovery and resource measures. Also, the availability of room for development for activities that cause nitrogen deposition in the Natura 2000 area concerned (temporarily) may be limited.

\subsection{Favourable conservation status and critical loads}

One might argue that a favourable conservation status means that there should be no critical load exceedances for nitrogen, and that this should be the objective of the PAS (De Heer et al., 2017). This point of view is based on the definition of a critical load, which is 'the quantitative estimate of an exposure to one or more pollutants below which significant harmful effects on specified sensitive elements of the environment are not expected to occur according to present knowledge' (Nilsson \& Grennfelt, 1988). In the Environmental Impact Assessment (EIA) of the PAS, the following alternatives to the PAS are taken into account (Ministry of Economic Affairs \& Ministry of Infrastructure and the Environment, 2015b):

- Autonomous development

- Alternative 1: Less emission reduction by agricultural sector (5 ktonne instead of 10 ktonne)

- Alternative 2: Less deposition room made available (30\% room instead of $56 \%$ )

- Alternative 3: A considerable extra national emission reduction by extra measures

- Alternative 4: A considerable extra local emission reduction by extra local measures Looking at these alternatives, achieving nitrogen levels below the critical load in all habitats and areas will be very difficult, even by the year 2030 (Figure 4.3; De Heer et al., 2017).

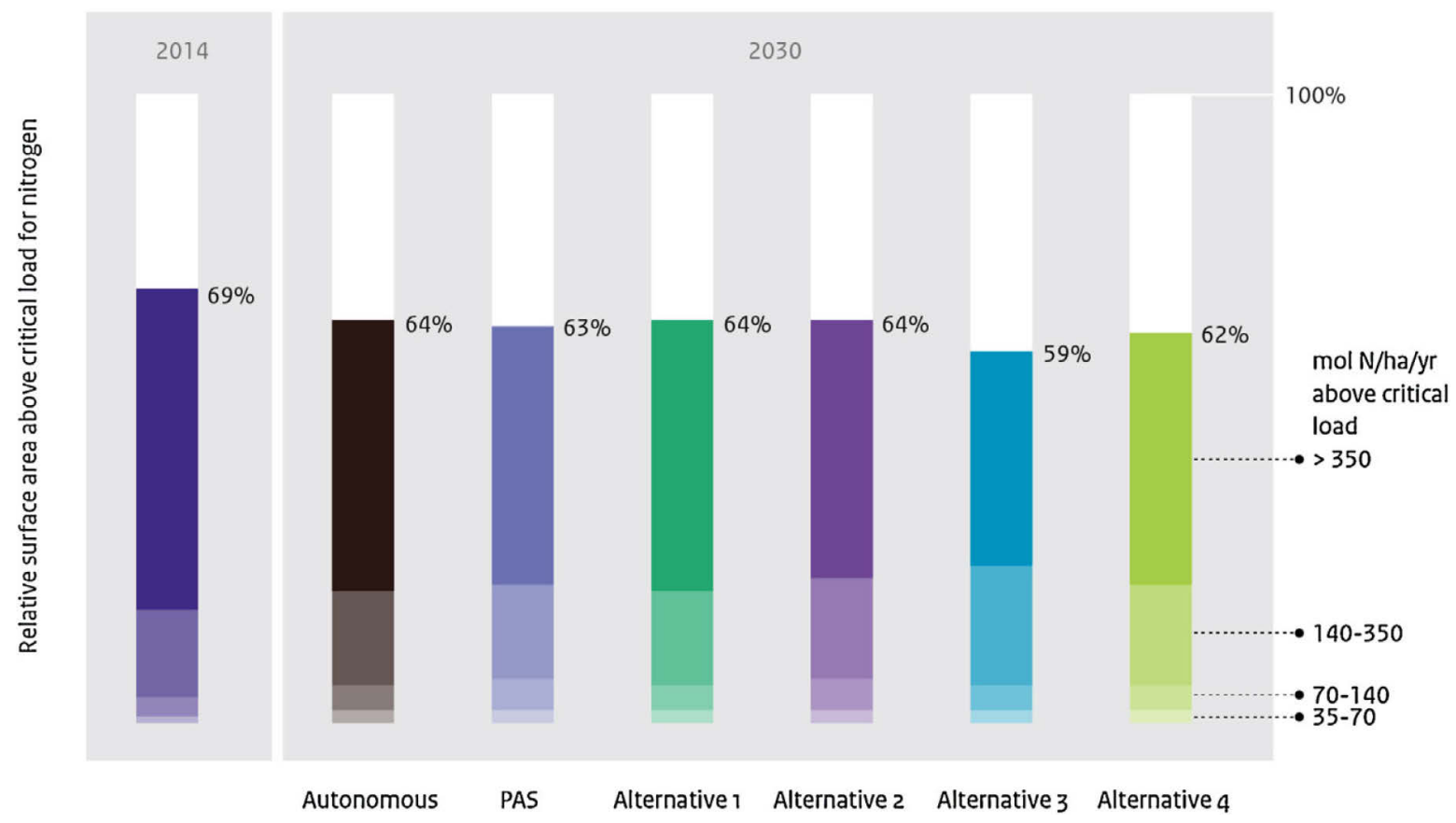

Figure 4.3 Exceedances of the critical load in nitrogen-sensitive habitat types and habitats of protected species in the PAS areas, for 2014 and 2030, under an autonomous scenario, the PAS and four alternatives to the PAS. Bars indicate the percentage of the total area Source: De Heer et al., 2017; modified from the Environmental Impact Assessment (Ministry of Economic Affairs \& Ministry of Infrastructure and the Environment, 2015b). 
Therefore, setting the critical load as an objective was considered not very realistic and politically not feasible. Early 2016, the Council of State ruled that 'the exceedance of the critical deposition load can be no more than an indication that deterioration of a habitat is not unlikely' (Council of State, 2016). This supports the idea that the critical load does not need to be the target. Still, compared to the autonomous situation, a considerable reduction of nitrogen deposition is possible, as shown in the EIA (Environmental Impact Assessment) by the PAS and alternatives 2 and 4 (the latter also including suspension of economic activities close to Natura 2000 areas) (Figure 4.4). Alternative 3 shows that taking even more emission reducing measures would result in a more positive effect on the decrease in nitrogen deposition (Figure 4.3) and, thus, on the nature objectives than is achieved under the PAS. However, these alternatives would have met with more resistance from economic stakeholders and would politically not have been feasible. For the PAS, the choice was made for a balance between benefits to nature and burden to society (De Heer et al., 2017). To achieve the conservation objectives, the strategy was chosen to combine reduction in deposition with ecological restoration measures (Ministry of Economic Affairs \& Ministry of Infrastructure and the Environment, 2015a).

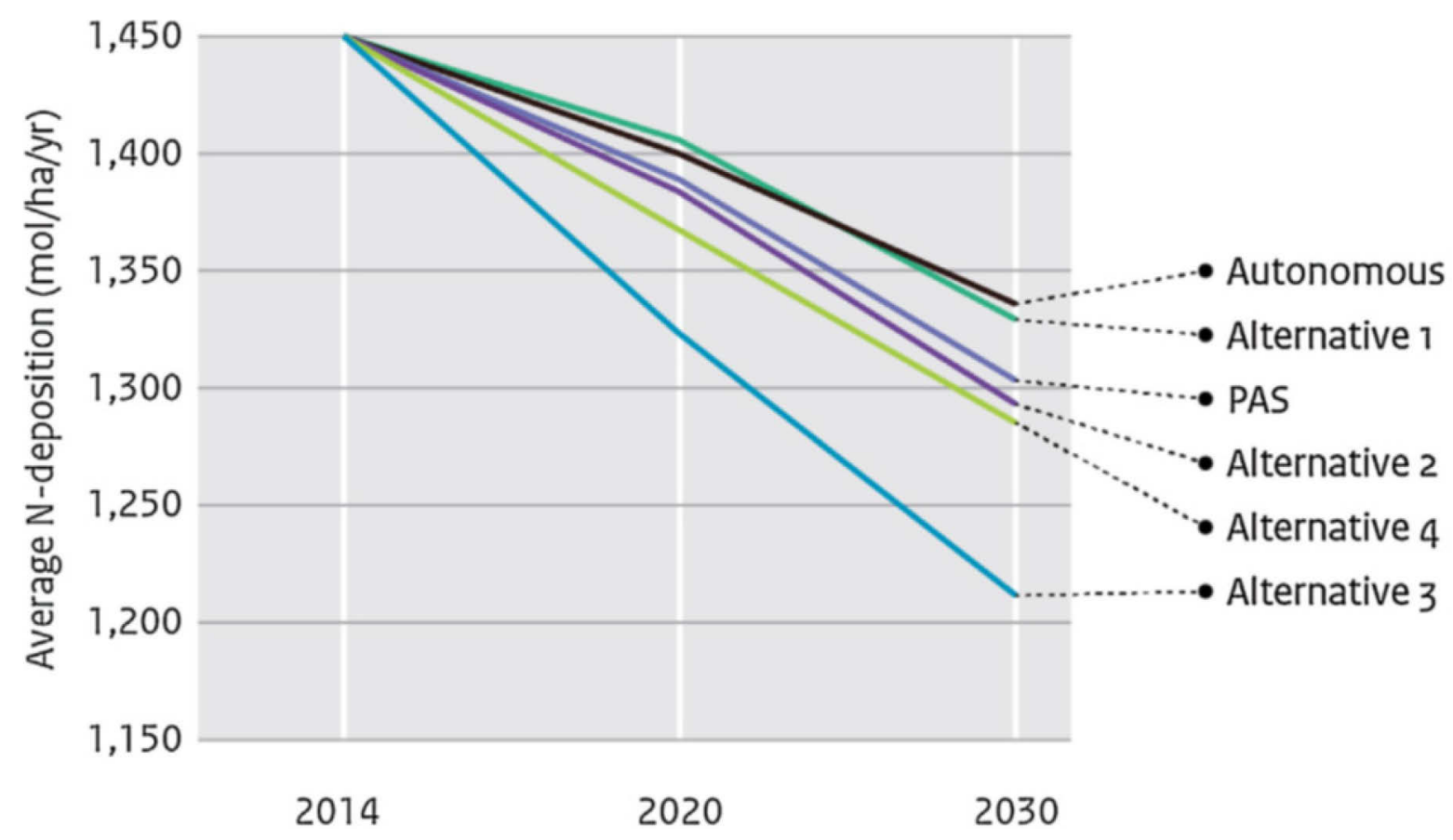

Figure 4.4 Trend in average nitrogen deposition in PAS areas Source: Environmental Impact Assessment (Ministry of Economic Affairs \& Ministry of Infrastructure and the Environment, 2015b). 


\section{Costs of ammonia-reduction measures}

\section{$5.1 \quad$ General}

In this chapter, the results are presented based on rules that are general for the case farms. There are also rules that are not general and will differ depending on the location of the farm, these are:

1. New initiatives may have an ammonia deposition at Natura 2000 areas of 1 or 0.05 mol per ha per year $(0.014$ or $0.0007 \mathrm{~kg} \mathrm{~N} / \mathrm{ha} /$ year). How much nitrogen deposition is caused by ammonia emissions at the farm location depends on the distance of the farm to nature and the wind direction, among other factors. Since the local situations of the case farms are not known, it is not possible to calculate the allowed ammonia emission at the farm location.

2. Due to extra local rules, it is possible that the farm cannot obtain all the room for development it needs. For instance, the province of Overijssel has, as other provinces have, implemented a rule that the room for development a farm can obtain, may at most cause an extra deposition at Natura 2000 areas of $3 \mathrm{~mol}$ per ha per year $(0.042 \mathrm{~kg} \mathrm{~N} / \mathrm{ha} / \mathrm{year})$. Since the local situations of the case farms are not known, it is not possible to calculate the allowed ammonia emissions at the farm location.

\section{$5.2 \quad$ Finishers}

\section{Expand the production from 7,200 to 14,400 finishers. Roughly speaking, that is from 2,500 to 5,000 animal places.}

The most common Dutch situation of the 2015 housing systems is taken into account here. That is, about $70 \%$ of the animals (1,750 animal places) is kept in a stable with an air scrubber with an average emission of $0.7 \mathrm{~kg}$ of $\mathrm{NH}_{3}$ per animal place per year and $30 \%$ of the animals (750 animal places) is kept traditionally, with an average emission of $3.0 \mathrm{~kg}$ of $\mathrm{NH}_{3}$ per animal place per year (Van Bruggen et al., 2017). At farm level, that is on average $1.39 \mathrm{~kg}$ of $\mathrm{NH}_{3}$ per animal place (70\% of $0,7 \mathrm{~kg}$ and $30 \%$ of $3.0 \mathrm{~kg}$ )Since it is common in the Netherlands to store all the manure under the stable floor, it is assumed that this is the case for all farms. In the rest of this section, we consider the situation of the ammonia rules of 2018 (see Section 4.1).

For this study, two scenarios are considered regarding the availability of room for development:

- There is no room for development available

- There is room for development available for $1.5 \mathrm{~kg}$ of $\mathrm{NH}_{3}$ per animal place.

A farm that has no significant negative impact on nitrogen-sensitive habitats and that wants to expand by 2,500 animal places has to keep these animals in a housing system with a maximum ammonia emission of $1.5 \mathrm{~kg}$ per animal place per year (Appendix 3). The same accounts for a farm that does have a negative influence on nitrogen-sensitive nature areas, but is able to obtain enough room for development to emit $3,750 \mathrm{~kg}$ of $\mathrm{NH}_{3}$ per year (based on availability of room for development; 2,500 animal places $* 1.5 \mathrm{~kg}$ of $\mathrm{NH}_{3}$ per animal place).

A farm that is not able to obtain room for development and that has a total lodge ammonia emission of $3,475 \mathrm{~kg}$ of $\mathrm{NH}_{3}$ (current situation; $1.39 \mathrm{~kg} /$ animal place $* 2,500$ animal places), cannot increase the total ammonia emission above this $3,475 \mathrm{~kg}$ of $\mathrm{NH}_{3}$ after expanding. The amount of $3,475 \mathrm{~kg}$ of $\mathrm{NH}_{3}$ can only be reached by changing the traditional housing system with 750 animal places for a new low-emission stable with 3,250 places $(750+2,500)$ that emits at most $2,250 \mathrm{~kg}$ of $\mathrm{NH}_{3}$ (existence farm situation of $3.475 \mathrm{~kg}$ - existence stable with air scrubber which emits $1.225 \mathrm{~kg}$ of $\mathrm{NH}_{3}$ ammonia), that is $0.69 \mathrm{~kg}$ per animal place per year. This is only possible with stables with air scrubbers that reduce the ammonia emission with $75 \%$ or more (Appendix 3 ). A combined air scrubber for a stable 
with 3,250 finishers costs $€ 10.10$ per pig place more than a traditional stable and $€ 5.10$ more than a stable with cooling (Table 5.1). This means that with no room for development available, the costs for a farmer that expands his farm with 2,500 pigs near one or more Natura 2000 areas are $€ 20,000$ yearly $(750 * 10,1+2,500 * 5,1)$ higher than the costs of a farm that has no significant negative impact on nitrogen-sensitive habitats. With the combined air scrubber (D 3.2.15.3), the ammonia emission is $0.45 \mathrm{~kg}$ of $\mathrm{NH}_{3}$ per animal place per year and $2,668 \mathrm{~kg}$ at farm level. It is expected that a farmer in this situation will decide to build a bigger stable for 5,000 places for the total ammonia emission room of $3,500 \mathrm{~kg}$ of $\mathrm{NH}_{3}$, or choose a cheaper stable with more ammonia emission and expand less.

Table 5.1 Extra investment and extra year costs per animal place for four different stables for housing of finishers compared to a traditional stable

\begin{tabular}{|c|c|c|c|c|c|}
\hline Stable type & $\begin{array}{l}\text { Stable } \\
\text { number }\end{array}$ & $\begin{array}{l}\text { Number of } \\
\text { finishers }\end{array}$ & $\begin{array}{r}\text { Extra investment } \\
(\mathrm{C}) \mathrm{b})\end{array}$ & $\begin{array}{l}\text { Extra year cost } \\
\text { investment }(\mathcal{C})\end{array}$ & $\begin{array}{l}\text { Extra year cost } \\
\text { exploitation }(\varepsilon)\end{array}$ \\
\hline Stable with Cooling & D 3.2.6.1 & 2,500 & 29 & 3.72 & 1.28 \\
\hline Combined air scrubber & D 3.2.15.3 & 2,500 & 42 & 6.10 & 4.60 \\
\hline Separated remov. of faeces a) & D 3.3 .16 & 2,500 & - & - & -2.00 \\
\hline
\end{tabular}

a) Rough estimate by author due to lack of information; b) Total investment cost traditional stable $€ 430$ per animal place per year; interest

$3.5 \%$; depreciation $4 \%$.

Source: Vermeij (2017), WUR (Wageningen Livestock Research).

\section{Conclusion}

A finisher farm that has a negative influence on nitrogen-sensitive nature areas and no room for development has yearly $€ 20,000$ higher housing cost when it expands from 2,500 to 5,000 finishers than a farm that has no significant negative impact on nitrogen-sensitive habitats or that has obtained enough room for development (Table 5.2). The case farm with no impact on nature or room for development emits after expansion $7,225 \mathrm{~kg}$ of $\mathrm{NH}_{3}$ at farm level and the case farm with impact on nature and no room for development $2,688 \mathrm{~kg}(0.7 * 1,750+0.45 * 3,250)$. Since room for development is expected to be limited, we can assume that many farmers near nature areas will have to deal with no room for development being available.

Table 5.2 Stable types, ammonia emission and extra year costs to three situations near a Natura 2000 area for a finisher farm that wants to expand from 2,500 to 5,000 places

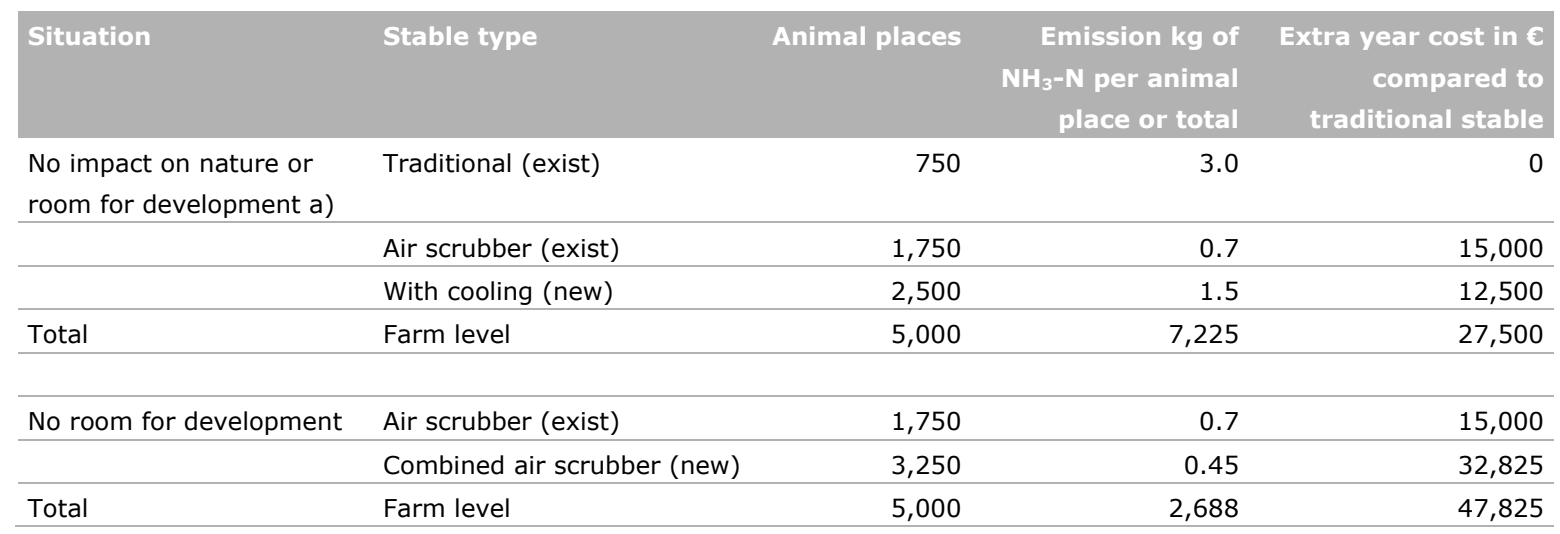

a) With room for development impact on nature may be at maximum $3 \mathrm{~mol}$ per ha. 


\subsection{Dairy cows}

\section{Expand the production from 120 to 240 dairy cows.}

A traditional cubicle housing system with slatted floor and a recirculation manure pit is taken into account, with an ammonia emission of $11.0 \mathrm{~kg}$ per animal place per year $(1,320 \mathrm{~kg}$ of ammonia deposition from housing). All the manure is stored under the stable floor.

Two scenarios regarding the availability of room for development are considered:

- There is no room for development

- There is room for development available for the maximum of $8.6 \mathrm{~kg}$ of $\mathrm{NH}_{3}$ per animal place in 2018.

In the 70s and 80s dairy farmers changed at mass from tied to cubicle houses. From the beginning of the 80 s till 2015 farms were limited by the milk quota. Buying milk quota was expensive and the incomes were sufficient, which is why many farmers did not change their farm between the 80 s and 2013. As from 2013, when it was known that the milk quota would be abolished, many new dairy housing systems were built. That's why for this study we assume that farmers who want to expand have old housing systems from the 70 s or 80 s that are written off and that farmers will build a new stable for all the 240 cows.

A farm that has no significant negative impact on nitrogen-sensitive habitats has to build a stable for 240 cows, with at most an ammonia emission of $8.6 \mathrm{~kg}$ of $\mathrm{NH}_{3}$ per animal place. The same accounts for a farm that does have a negative influence on nitrogen-sensitive nature areas, but is able to obtain enough room for development. This study assumes on average more than 720 grazing hours per cow per year. For dairy cattle with more than 720 grazing hours a year, the housing emission of ammonia per animal place is $5 \%$ lower than for dairy cattle with less than 720 grazing hours. In the RAV list (Appendix 3) the emission factors for dairy cattle with an emission of less than 720 grazing hours are mentioned.

A farm that is not able to obtain room for development and that has a total lodge ammonia emission of $1,320 \mathrm{~kg}$ of $\mathrm{NH}_{3}$, cannot increase the total ammonia emission above this $1,320 \mathrm{~kg}$ of $\mathrm{NH}_{3}$ after expanding. Taking into account 240 cows, that means an emission of no more than $5.5 \mathrm{~kg}$ of $\mathrm{NH}_{3}$ per animal place per year. This can only be achieved by changing the current housing system for a new low-emission stable. Actually, in this case a few cubicle housing systems apply, which are slatted floor with a balling rubber top layer and seal off flaps in the grid chinks and stables with air scrubbers. In other cases, with a different amount of cows, a tied stable also may be an option. A farm that has no significant negative impact on nitrogen-sensitive habitats could build a stable with longitudinal grooves, but a farm that has significant negative impact on nitrogen-sensitive habitats has to build for instance a stable with an air scrubber. The difference in housing costs between these two stables are $€ 63.30((€ 65+€ 6.70)-(€ 7.30+€ 1.10))$ per cow place per year (Table 5.3) and at farm level $€ 15,192$ per year.

Table 5.3 Extra investment and extra year costs per animal place for three different stables for housing of dairy cows compared to a traditional stable

\begin{tabular}{|c|c|c|c|c|}
\hline Stable type & Stable number & $\begin{array}{r}\text { Extra investment } \\
\text { (e) b) }\end{array}$ & $\begin{array}{l}\text { Extra year cost } \\
\text { investment }(\varepsilon)\end{array}$ & $\begin{array}{l}\text { Extra year cost } \\
\text { exploitation }(\varepsilon)\end{array}$ \\
\hline Stable with longitudal grooves & A 1.24 & 86 & 7.30 & 1.10 \\
\hline Stable with air scrubber a) & A 1.17 & 648 & 65.00 & 6.70 \\
\hline
\end{tabular}

a) This stable is mechanical ventilated. Common is that al stables for dairy are natural ventilated; b) Total investment cost traditional stable $€ 4,000$ per animal place per year; interest $3.5 \%$; depreciation $4 \%$. Source: Vermeij, 2017, WUR (Wageningen Livestock Research). 


\section{Conclusion}

A dairy farm that has a negative influence on nitrogen-sensitive nature areas and no room for development yearly has about $€ 15,000$ higher housing cost when it expands from 120 to 240 dairy cows than a farm that has no significant negative impact on nitrogen-sensitive habitats or enough room for development (Table 5.4). The case farm with no impact on nature or room for development emits after expansion $2,064 \mathrm{~kg}$ of $\mathrm{NH}_{3}$ at farm level and the case farm with impact on nature and no room for development $1,164 \mathrm{~kg}\left(4.85^{*} 240\right)$. Since the room for development is expected to be limited, we can assume that many farmers near nature areas will have to deal with no room for development being available.

Table 5.4 Stable types, ammonia emission and extra year costs to three situations near a Natura 2000 area for a dairy farm that wants to expand from 120 to 240 cow places

\begin{tabular}{|c|c|c|c|c|}
\hline Situation & Stable type & Animal places & $\begin{array}{r}\text { Emission } \mathrm{kg} \text { of } \\
\mathrm{NH}_{3}-\mathrm{N} \text { per animal } \\
\text { place or total }\end{array}$ & $\begin{array}{r}\text { Extra year cost in } € \\
\text { compared to } \\
\text { traditional stable }\end{array}$ \\
\hline Total & Farm level & 240 & 2,064 & 2,016 \\
\hline No room for development & Air scrubber & 240 & 4.85 & 17,208 \\
\hline Total & Farm level & 240 & 1,164 & 17,208 \\
\hline
\end{tabular}

a) With room for development impact on nature may be at maximum $3 \mathrm{~mol}$ per ha.

\section{$5.4 \quad$ Broilers}

\section{Expand the production from 300,000 to 600,000 broilers. Roughly speaking, that is from 40,000 to 80,000 animal places.}

The most common Dutch housing system in 2015 is taken into account, which is a loose housing system with mixed air ventilation and solid manure, with an ammonia emission of $0.037 \mathrm{~kg}$ per animal place per year.

Two scenarios regarding the availability of room for development are considered:

- There is no room for development

- There is room for development available for the maximum of $0.035 \mathrm{~kg}$ of $\mathrm{NH}_{3}$ per animal place in 2018.

A farm that has no significant negative impact on nitrogen-sensitive habitats and that wants to expand with 40,000 broilers has to build a housing system with an ammonia emission of at maximum $0.035 \mathrm{~kg}$ per animal place per year. For instance a stable with heaters. The same accounts for a farm that does have a negative influence on nitrogen-sensitive nature areas, but is able to obtain enough room for development to emit $1,400 \mathrm{~kg}$ of $\mathrm{NH}_{3}$.

A farm that is not able to obtain room for development and that has a total lodge ammonia emission of $1,480 \mathrm{~kg}$ of $\mathrm{NH}_{3}$, cannot increase the total ammonia emission above these $1,480 \mathrm{~kg}$ of $\mathrm{NH}_{3}$ after expanding. This can be achieved by changing the existing housing with tube heating (480 $\mathrm{kg}$ of $\mathrm{NH}_{3}$ ). Then there are investment costs for installation of the tube heating system. These investment costs are about $15 \%$ for newly built stables. The equipment for mixed air ventilation has a residual value and can be sold. In addition, the farmer may save at energy costs compared to a stable with mixed air ventilation. As a result, the yearly costs of the altered stable are pretty similar to the costs in the old situation (Vermeij, 2017).

In addition, to keep the 40,000 broilers, a new stable with an ammonia emission of at most $1,000(1,480-480) \mathrm{kg}$ of $\mathrm{NH}_{3}$ or $1,160(1,480-320) \mathrm{kg}$ of $\mathrm{NH}_{3}$ emission must be built. That is an 
emission of 0.025 or $0.029 \mathrm{~kg}$ of $\mathrm{NH}_{3}$ per animal place, or on average $0.027 \mathrm{~kg}$ of $\mathrm{NH}_{3}$ per animal place. A stable with a maximum of $0.027 \mathrm{~kg}$ of $\mathrm{NH}_{3}$ per place is a stable with a heat exchanger (Table 5.3, E 5.11). This stable has higher investment costs than a stable with heaters, but the savings on energy costs are higher. Thus there are no extra costs for this stable.

For the difference in investment and year costs for the stables that have to be built for broilers when expanding, see Table 5.5. A farm that has no significant negative impact on nitrogen-sensitive habitats and that wants to expand has to build at least a housing system with heaters (E 5.14). Due to greater savings at energy costs, this stable is even cheaper than a traditional housing system.

Table 5.5 Extra investment and extra year cost per animal place per year for four different stables for housing of broilers compared to a stable for mixed air ventilation

\begin{tabular}{|c|c|c|c|c|}
\hline Stable type & Stable number & $\begin{array}{r}\text { Extra investment } \\
(\mathrm{c}) \mathrm{a})\end{array}$ & $\begin{array}{l}\text { Extra year cost } \\
\text { investment }(C)\end{array}$ & $\begin{array}{l}\text { Extra year cost } \\
\text { exploitation ( }(\varepsilon)\end{array}$ \\
\hline Stable with heaters & E 5.14 & 0.20 & 0.03 & -0.06 \\
\hline Stable with tube heating & E 5.15 & 0.60 & 0.06 & -0.06 \\
\hline Stable with heat exchanger & E 5.11 & 0.90 & 0.09 & -0.14 \\
\hline
\end{tabular}

a) Total investment costs for a traditional stable are $€ 15$ per animal place per year; interest $3.5 \%$; depreciation $4 \%$.

Source: Vermeij, 2017, WUR (Wageningen Livestock Research).

\section{Conclusion}

Broiler farms that want to expand, typically need to invest in housing systems with heaters. Strikingly, these stables are cheaper than a traditional housing system, due to greater savings of energy costs.

Therefore, a broiler farm that has no negative influence on nitrogen-sensitive nature areas or that has obtained enough room for development, has on average $€ 1,200$ lower housing costs when it expands from 40,000 to 80,000 broilers than a farm with traditional housing. A farm that has a significant negative impact on nitrogen-sensitive habitats and does not have any room for development, will even have $€ 2,000$ lower housing costs when it expands (Table 5.6). Since the room for development is expected to be limited, we can assume that many farmers near nature areas will have to deal with no room for development being available.

Table 5.6 Stable types, ammonia emission and extra year costs to three situations near a Natura 2000 area for a broiler farm that wants to expand from 40,000 to 80,000 places

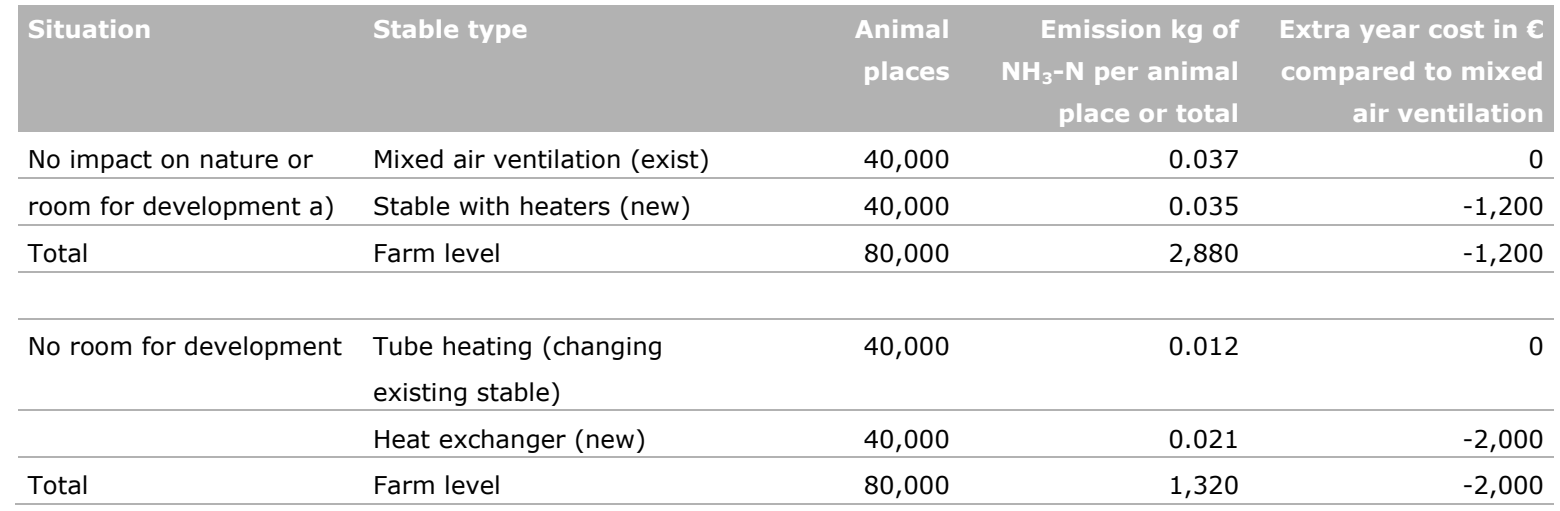

a) With room for development, impact on nature may be at maximum $3 \mathrm{~mol}$ per ha. 


\section{$6 \quad$ National situation}

Table 6.1 gives a summary of the results of the extra costs a farmer close to a Natura 2000 area has to make compared to a farm with no influence on a Natura 2000 area, in case the case farms expand by $100 \%$. Whether farmers have to make extra costs depends on the availability of room for development and on the local and national rules that are in place. For the province of Overijssel for instance, there is room for development available, but farms can only obtain it up to an extra deposition at Natura 2000 areas of $3 \mathrm{~mol}$ per ha $(0.042 \mathrm{~kg} \mathrm{~N} / \mathrm{ha})$. The amount of emission that is allowed depends on the exact location of the farm (distance but also main wind direction; this can be calculated with AERIUS model) with respect to the Natura 2000 area. Room for development is in principle made available to animal husbandry as a sector for a period of six years, as from 2015 . For farmers that want to apply for a permit, first come first serve applies. In some regions in the Netherlands, for example in the province of Friesland, all room for development has already been issued and new applications are not accepted in the coming years. At the moment, enough room for development is available in Overijssel to issue permits for projects that fall into segment 2

(Figure 4.1). As said before in Section 4.6, farmers in Overijssel could also have an impact on nitrogen-sensitive Natura 2000 areas in Friesland, which means that they also could be hindered when they cause too much deposition in nature areas in Friesland, when there is no room for development for the nature areas in Friesland (meaning that they might not be able to obtain room for development as well).

Keeping in mind these rules, farms that want to expand with influence at Natura 2000 areas may be confronted with two situations:

1. There is no room for development available.

2. There is room for development available; as a rule, the extra emission may not lead to a deposition on a Natura 2000 area that exceeds 3 mol per hectare per year.

Table 6.1 Extra year costs $(€)$ compared to the farms with no significant negative impact on Natura 2000 areas for the case farms in the vicinity of Natura 2000 areas in the Netherlands, for different situations when they want to expand by $100 \%$

\begin{tabular}{lrrrrrr} 
Amount of room for & Finisher & Finisher & Dairy & Dairy & Broiler & Broiler \\
development & $4,00 \mathrm{~m}$ & $2,000 \mathrm{~m}$ & $4,00 \mathrm{~m}$ & $2,000 \mathrm{~m}$ & $4,00 \mathrm{~m}$ & $2,000 \mathrm{~m}$ \\
$100 \%$ room a) & 0 & 0 & 0 & 0 & 0 & 0 \\
\hline No room & 20,325 & 20,325 & 15,825 & 15,825 & 0 & 0 \\
\hline
\end{tabular}

a) Impact on nature may be at maximum $3 \mathrm{~mol}$ per ha, if not than there are extra costs with an maximum of the cost of the situation of no room for development.

If room for development is available to the case farm, there are no extra costs involved when the farm is expanding (as long as the deposition on a Natura 2000 area does not exceed 3 mol per hectare per year). However, if no room for development is available at all, the farm has to make extra costs of about $€ 20,000$ for finishers and almost $€ 16,000$ for dairy (see Table 6.1 ).

The number of farms is gradually declining and farms close to nature areas are smaller than the national average. As smaller farms generally have more difficulty to generate a good income than bigger farms, a larger part of farms that are located near nature areas is expected to stop farming than farms that are located further away from nature.

When finisher or dairy farms that have a significant negative influence on nitrogen-sensitive Natura 2000 habitats want to expand their production, they have to make higher costs than farms that have no negative influence. This is because they have to build more expensive housing systems, that reduce ammonia emissions. As a result, it is expected that: 
1. a part of the farmers that wants to expand will buy a farm located further away from nature and will expand at the new location; or

2. other farmers will choose to continue farming at the current location and combine the farm with for example recreational activities to generate more income. As nature areas provide excellent possibilities for walking and biking, farms in the vicinity of nature have good opportunities to make money in recreation, for instance by creating a farmers campsite.

Due to these two aforementioned reasons, it is expected that only a small number of farms that are expanding, have a negative influence on nature. In the Netherlands, regional policy is in place to stimulate that farms with a high negative influence on nitrogen-sensitive nature are moving to areas with no negative influence on nature; the new buildings can then be partly subsidised.

De Koeijer et al. (2014) expect that about 30\% of the bigger farms have plans to expand within a period of five years. Small farms ( $40 \%$ of the total amount of farms) have no plans to expand (De Koeijer et al., 2014). The number of dairy farms within 2,000 m from a Natura 2000 area in the Netherlands in 2016 is presented in Appendix 2. How many of them want to expand between now and next 5 years, is calculated in Table 6.2. Farms for finishers and broilers that are located within $2,000 \mathrm{~m}$ from Natura 2000 are about $65 \%$ of the size of the average farm; $60 \%$ of these farms are small (instead of $40 \%$ ) and have no plans to expand. It is to be expected that about 1,800 farms that are located within 2,000 m of Natura 2000 areas want to expand between now and five years (Table 6.2); only 45 of them are farms with finishers and 12 of them keep broilers.

Table 6.2 Number of animal farms near 2,000 $\mathrm{m}$ of a Natura 2000 area and the expected number of farms that want to expand the next five years

\begin{tabular}{|c|c|c|c|c|}
\hline Farm type & Number in 2016 & $\begin{array}{r}\text { Number want to } \\
\text { expand }\end{array}$ & $\begin{array}{l}\text { Expected number } \\
\text { of animal places }\end{array}$ & Type of animals \\
\hline Dairy farms & 4,730 & 850 & 86,000 & cows \\
\hline Broilers & 97 & 12 & $1,115,000$ & broilers \\
\hline Other animal farms & 4,907 & 880 & i.r. & \\
\hline
\end{tabular}

A part of the 1,800 farms that want to expand will be able to obtain enough room for development. In that case, they will not have any extra costs compared to a farm that has no influence at a Natura 2000 area. Moreover, there will probably also be a number of farms that will buy another farm outside the influence of a Natura 2000 area in order to be able to expand the production.

When we assume that half of the farms that want to expand have lack of room for development and stay at the current location, about 425 dairy farms, 22 farms with finishers, 6 farms with broilers and 440 other farms with animals that are located within 2,000 m of a Natura 2000 area, have to make extra costs when expanding. Because the existing farms are smaller than the case farm, this means 358 dairy farms equal to the size of the case farm and 18 finisher farms equal to the size of the case farm. This means yearly about $€ 5.7 \mathrm{~m}$ ( $€ 15,825 * 358$ farms) extra cost for the dairy sector and $€ 0.4 \mathrm{~m}$ ( $€ 20,325 * 18$ farms) for the finisher farms. There are no extra costs for the broiler farms that expand. The average extra costs for dairy, finisher and broiler farms are about $€ 13,500$ per farm per year (total extra costs $€ 6.1 \mathrm{~m}(5.7+0.4+0.0)$ divided by 453 farms $(425+22+6)$ ). Assuming that the extra cost would be also $€ 13,500$ per farm for other animal farms, the total extra costs at the national level would be calculated at about $€ 12 \mathrm{~m}$ per year. Most of the other animal farms (75\%) are other grazing animal farms (not being dairy farms). The costs for these farms when they expand will probably be lower. Consequently, the extra costs at the national level for farms that expand in the next five years and are located within 2,000 m from Natura 2000 areas with a deposition of less than $3 \mathrm{~mol}$ per hectare on nature areas will be between $€ 9 \mathrm{~m}$ and $€ 13 \mathrm{~m}$ yearly. 


\section{$7 \quad$ Conclusions}

In this study, we examined the extra costs a farmer close to a Natura 2000 area has to make compared to a farmer with no influence on a Natura 2000 area, when they both want to expand the farm by $100 \%$. Whether farmers have to make extra costs depends on the actual impact that the farm has on nitrogen-sensitive Natura 2000-habitats in terms of nitrogen deposition, the availability of room for development and on the local and national rules that are in place. Room for development is the quantity of nitrogen deposition that is available for projects and activities that need a permit. There is also room reserved for projects and activities that are exempted from compulsory licensing: autonomous growth, such as a road traffic increase, and initiatives causing less than 1 mol nitrogen deposition per hectare per year $(0.014 \mathrm{~kg} \mathrm{~N} / \mathrm{ha})$ in nitrogen-sensitive areas.

Room for development is in principle made available to animal husbandry as a sector for a period of six years, as from 2015. It must be requested for all new activities that cause a nitrogen deposition on a nitrogen-sensitive habitat type of at least $1 \mathrm{~mol}$ per hectare per year. Sometimes, one activity can cause nitrogen deposition in several Natura 2000 areas at the same time. Room for development can be granted, if it is available and if the application complies with the provincial policies.

Room for development is made available at different moments in time, so that it cannot be exhausted all at once. In principle, applications are processed in order of entry. Some provinces have determined that projects or activities must start within a specified period after licensing (within two years after the permit is granted in Overijssel). It is not possible to issue more room for development than there is available.

In some regions in the Netherlands, all room for development has already been issued and new applications are not accepted (temporarily). In the province of Overijssel, there is still room for development available. As a provincial rule, farms can only obtain up to $3 \mathrm{~mol}$ per ha $(0.042 \mathrm{~kg} \mathrm{~N} / \mathrm{ha})$ of extra deposition. The amount of ammonia emission that is allowed depends on the exact location of the farm with respect to the nitrogen-sensitive Natura 2000 area or areas (distance and main wind direction are important factors in that respect); the closer the farm is to a Natura 2000 area, the higher the nitrogen deposition is.

In 2016, there were about 55,500 farms in the Netherlands, of which 16,500 were dairy farms, 1,600 finisher farms and almost 500 broiler farms. On these farms, 4.3 million cattle, including 1.8 million dairy cows, 12.5 million pigs and 105 million chickens were kept. Almost $30 \%$ of the agricultural area, $28 \%$ of the dairy cows, $18 \%$ of the finishers and $17 \%$ of the broilers in the Netherlands are located within 2,000 m of at least one Natura 2000 area. Finisher and broiler farms that are located near a Natura 2000 area are about 30\% smaller than the Dutch average.

Farms that have an impact on nitrogen-sensitive Natura 2000 areas that want to expand may be confronted with two situations: there is enough room for development for an extra nitrogen deposition up to $3 \mathrm{~mol}$ per hectare per year, or there is no room for development left. If room for development is available to the case farm, there are no extra costs involved when the farm is expanding (as long as the extra deposition on a Natura 2000 area does not exceed 3 mol per hectare per year). However, if no room for development is available at all, the farm has to make extra costs of about $€ 20,000$ for finishers and almost $€ 16,000$ for dairy. This is because they have to build more expensive housing systems, that reduce ammonia emissions. So we conclude that finisher or dairy farms that have a significant negative influence on nitrogen-sensitive Natura 2000 habitats that want to expand their production, have to make higher costs than farms that have no negative influence. Broiler farms have no extra costs.

De Koeijer et al. (2014) have estimated that about $18 \%$ of the dairy farms have plans to expand within a period of five years. Based on the De Koeijer et al (2014), we calculated that about $12 \%$ of 
the farms with finishers and broilers have plans to expand within five years. Taking into account more than 10,000 farms that are located within 2,000 m from a Natura 2000 area, we calculated how many of them want to expand between now and next 5 years. We expect that about 1,800 farms want to expand; 850 dairy farms, 45 farms with finishers, 12 farms that keep broilers and 880 farms with other animals.

A part of the 1,800 farms that want to expand will be able to obtain enough room for development. In that case, they will not have any extra costs compared to a farm that has no influence at a Natura 2000 area when the extra deposition on a Natura 2000 area does not exceed 3 mol per hectare per year. Moreover, there will probably also be a number of farms that will buy another farm outside the influence of a Natura 2000 area in order to be able to expand the production.

When we assume that half of the farms that want to expand have lack of room for development and stay at the current location, about 900 farms with animals that are located within 2,000 m of a Natura 2000 area, have to make extra costs when expanding. The costs are estimated at $€ 5.7$ million per year for the dairy sector and $€ 0.4$ million per year for finisher farms. There are no extra costs for broiler farms that expand. Based on the average extra costs for dairy, finisher and broiler farms, the extra costs for other animal farms are estimated at €2.5-7 million at the national level. Consequently, the extra costs at the national level for farms that expand in the next five years and that are located within 2,000 $\mathrm{m}$ from Natura 2000 areas will be between $€ 9$ and $€ 13$ million yearly. There would also be extra costs for farmers with room for development and an extra deposition on a Natura 2000 area that exceeds the $3 \mathrm{~mol}$ per hectare. This costs are not calculated in this study. 


\section{References and websites}

Aerius (2017). website: https://www.aerius.nl/en

Backus, C. and A. Keessen (2017). The Netherlands - national report on the legal framework for ammonia regulation of livestock installations with a particular regard to Natura 2000- sites. Utrecht, university, Draft report.

CBS (2017). Den Haag, Centraal bureau voor de Statistiek, www.cbs.nl; statline.

Council of State (2016). Ruling 201406537/1/R2 and 201406589/1/R2. The Hague: Council of State. Ministry of Economic Affairs \& Ministry of Infrastructure and the Environment (2015a). Programma Aanpak Stikstof 2015-2021 zoals gewijzigd na partiële herziening op 15 december 2015. The Hague.

Heer, M. de, F. Roozen and R. Maas (2017). The Integrated Approach to Nitrogen in the Netherlands: A preliminary review from a societal, scientific, juridical and practical perspective, Journal for Nature Conservation 35 (2017), pp. 101-111.

http://pas. natura2000.nl/pages/veelgestelde-vragen.aspx

http://pas.natura2000.nl/pages/verdeling-van-de-depositieruimte.aspx

http://wetten.overheid.nl/BWBR0036748/2017-01-01\#Bijlage1

http://www.agrimatie.nl/ Agrarische feiten en cijfers. Den Haag, Wageningen Economic Research, website

Jacobson, B.H. and L. Stahl (2017). Economic analysis of the ammonia regulation in Denmark in relation to the Habitat directive. Copenhagen, Department of food and Resource Economics (IFRO) University of Copenhagen, Draft version $17^{\text {th }}$ October.

Jansen, A.J.M., H.F. van Dobben, M.E. Nijssen, J.H. Bouwman and D. Bal (eds.) (2014). Herstelstrategieën stikstofgevoelige habitats. Ecologische onderbouwing van de Programmatische Aanpak Stikstof (PAS). Deel III: Landschapsecologische inbedding. Unie van Bosgroepen, Alterra Wageningen UR, Stichting Bargerveen \& Programmadirectie Natura 2000, Ministerie van Economische Zaken.

Koeijer, T.J. de, P.W. Blokland, J.F.M. Helming and H.H. Luesink (2014). Ex ante evaluatie wetsvoorstel Voorwaarden groei melkveehouderij. Den Haag, LEI Wageningen UR, Rapport 2014019.

Ministry of Economic Affairs, LTO, Netherlands, NZO, Nevedi, NMV, NVP, NVV, CUMELA Netherlands (2014). Overeenkomst generieke maatregelen in verband met het programma aanpak stikstof.

Ministry of Economic Affairs \& Ministry of Infrastructure and the Environment (2015a). Programma Aanpak Stikstof 2015-2021 zoals gewijzigd na partiële herziening op 15 december 2015. The Hague.

Ministry of Economic Affairs \& Ministry of Infrastructure and the Environment (2015b). Plan-MER over het programma aanpak stikstof 2015-2021. Deel 1. The Hague.

Nilsson, J., \& Grennfelt, P. (1988). Critical loads for sulphur and nitrogen. report from a workshop held at skokloster, Sweden 19-24 March, 1988. NORD miljørapport1988:15. Copenhagen: NORD.

PAS (2017). website: http://pas.natura2000.nl/pages/verdeling-van-de-depositieruimte.aspx

Provincie Overijssel (2015). Beleidsregel toedeling ontwikkelingsruimte Programmatische Aanpak Stikstof Overijssel 2015 segment 2, 2015/0156224, 30 juni 2015

RVO (2017). Assen, Rijksdienst Voor Ondernemend Nederland. http://www.rvo.nl/onderwerpen/agrarisch-ondernemen/mest-en-grond/mest

Smits, N.A.C. and B. Bal (eds.) (2014). Herstelstrategieën stikstofgevoelige habitats. Ecologische onderbouwing van de Programmatische Aanpak Stikstof (PAS). Deel I: Algemene inleiding herstelstrategieën: beleid, kennis en maatregelen, Alterra Wageningen UR \& Programmadirectie Natura 2000 van het Ministerie van Economische Zaken.

Smits, N.A.C., A.S. Adams, D. Baland H.M. Beije (eds.) (2014). Herstelstrategieën stikstofgevoelige habitats. Ecologische onderbouwing van de Programmatische Aanpak Stikstof (PAS). Deel II: Herstelstrategieën voor stikstofgevoelige habitats. Alterra Wageningen UR \& Programmadirectie Natura 2000 van het Ministerie van Economische Zaken. 
Van Bruggen, C., A. Bannink, C.M. Groenestein, B.J. de Haan, J.F.M. Huijsmans, H.H. Luesink, S.M. van der Sluis, G.L. Velthof and J. Vonk (2017). Emissies naar lucht uit de landbouw 2015. Berekeningen met het Nationaal Emissiemodel voor Ammoniak (NEMA). Draft-report. WOT Natuur \& Milieu, Wageningen UR, Wageningen.

Van Dobben, H.F., R. Bobbink, D. Bal and A. van Hinsberg, A. (2014). Overview of critical loads for nitrogen deposition for Natura 2000 habitat types occurring in The Netherlands. Alterra report 2488. Wageningen: Alterra.

Van Zanten, M.C., R.J. Wichink Kruit, R. Hoogerbrugge, E. Van der Swaluw and W.A.J. van Pul (2017). Trends in ammonia measurements in the Netherlands over the period 1993-2014, Atmospheric Environment, 148 (2017), pp. 352-360.

Vermeij, I. (2017). Investment and year cost of stables for finishers, dairy cows and broilers. Lelystad, Wageningen Livestock Research, Personal information. 


\section{Appendix 1 Characteristics of the cases and the case farms before expanding}

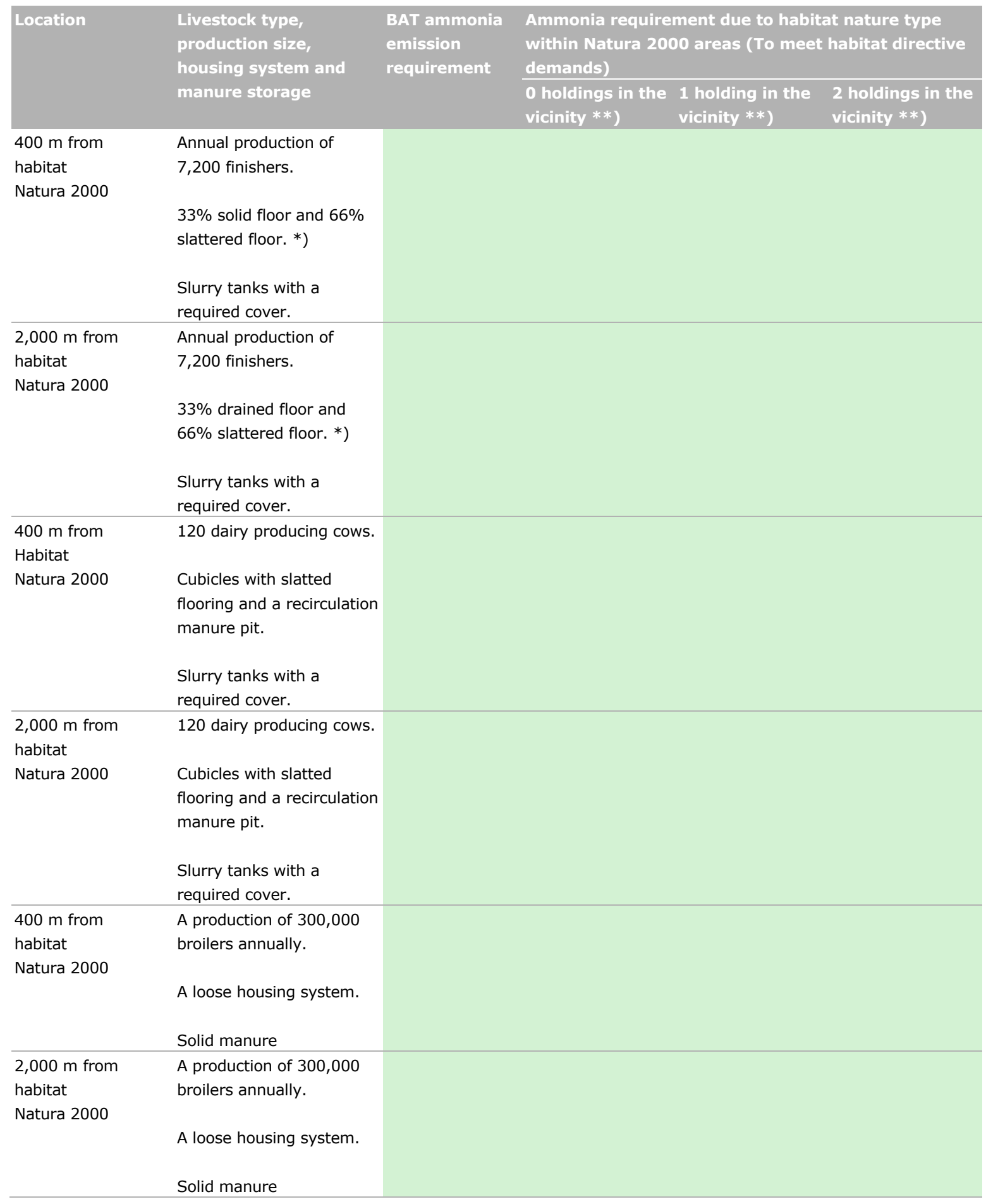

*) For the Netherlands the most common housing system.

**) For the Netherlands it depends on the room for ammonia deposition. 


\section{Appendix 2 Overview Dutch agriculture near nature}

Table A2.1 Agriculture production near nature area's in 2016

\begin{tabular}{|c|c|c|c|c|c|}
\hline Description & Netherlands & $\begin{array}{r}\text { Natura } 2000 \\
<400 m\end{array}$ & $\begin{array}{r}\text { Natura } 2000 \\
>400 \mathrm{~m} \text { and } \\
<2,000 \mathrm{~m}\end{array}$ & $\begin{array}{r}\text { Other nature } \\
<400 \mathrm{~m}\end{array}$ & $\begin{array}{r}\text { Other nature } \\
>400 \mathrm{~m} \text { and } \\
<2,000 \mathrm{~m}\end{array}$ \\
\hline Number of farms & 55,681 & 3,639 & 12,605 & 17,796 & 7,067 \\
\hline \multicolumn{6}{|l|}{ Total agricultural area $(: 1,000 \mathrm{ha})$} \\
\hline Grassland & 975 & 79 & 232 & 348 & 157 \\
\hline Green feed crops & 216 & 13 & 49 & 71 & 39 \\
\hline Arable crops & 504 & 25 & 122 & 142 & 90 \\
\hline Horticulture & 101 & 6 & 25 & 25 & 20 \\
\hline \multicolumn{6}{|l|}{ Number of animals $(: 1,000)$} \\
\hline Cattle total & 4,251 & 278 & 976 & 1,346 & 891 \\
\hline Dairy cows & 1,745 & 101 & 382 & 541 & 387 \\
\hline Young dairy cattle & 1,317 & 77 & 286 & 411 & 266 \\
\hline Sheep & 784 & 83 & 186 & 282 & 62 \\
\hline Goats & 500 & 21 & 120 & 142 & 163 \\
\hline Total pigs & 12,479 & 282 & 2,074 & 3,323 & 3,241 \\
\hline Finishers & 5,726 & 112 & 943 & 1,570 & 1,378 \\
\hline Sows & 931 & 25 & 157 & 248 & 262 \\
\hline Chickens total & 105,620 & 1,954 & 19,407 & 28,201 & 23,602 \\
\hline Laying hens (incl. youngsters) & 46,212 & 822 & 10,382 & 16,000 & 9,538 \\
\hline Broilers & 49,188 & 728 & 7,735 & 10,071 & 10,738 \\
\hline Parents for broilers & 8,742 & 268 & 1,037 & 1,874 & 2,855 \\
\hline Finishers & 5,726 & 112 & 943 & 1,570 & 1,378 \\
\hline
\end{tabular}

Source: Dutch National Agricultural Census (CBS,2017), edited by Wageningen Economic Research.

Table A2.2 Number of farms per farmtype near nature areas in The Netherlands in 2016

\begin{tabular}{|c|c|c|c|c|c|}
\hline Description & Netherlands & $\begin{array}{r}\text { Natura } 2000 \\
<400 \mathrm{~m}\end{array}$ & $\begin{array}{r}\text { Natura } 2000 \\
>400 \mathrm{~m} \text { and } \\
<2,000 \mathrm{~m}\end{array}$ & $\begin{array}{r}\text { Other nature } \\
<400 \mathrm{~m}\end{array}$ & $\begin{array}{r}\text { Other nature } \\
>400 \mathrm{~m} \text { and } \\
<2,000 \mathrm{~m}\end{array}$ \\
\hline Arable farms & 10,821 & 662 & 2,455 & 3,437 & 963 \\
\hline Horticulture farms & 7,389 & 388 & 1,582 & 1,755 & 1,411 \\
\hline Remaining culture farms & 1,612 & 137 & 546 & 575 & 197 \\
\hline Grazing animal farms & 27,910 & 2,111 & 6,348 & 9,672 & 3,156 \\
\hline - Dairy farms & 16,503 & 1,051 & 3,679 & 5,418 & 2,885 \\
\hline Shed animal farms & 4,837 & 152 & 933 & 1,345 & 954 \\
\hline - Finishers & 1,648 & 51 & 324 & 462 & 241 \\
\hline - Breeding farms & 806 & 32 & 141 & 222 & 202 \\
\hline - Other pig farms & 681 & 15 & 124 & 193 & 119 \\
\hline - Laying hen farms & 638 & 17 & 158 & 192 & 149 \\
\hline - Broiler farms & 468 & 13 & 84 & 107 & 94 \\
\hline Crop combination farms & 1,076 & 72 & 293 & 315 & 141 \\
\hline Cattle combination farms & 607 & 22 & 120 & 215 & 107 \\
\hline All other combination farms & 1,429 & 95 & 328 & 482 & 138 \\
\hline Total & 55,681 & 3,639 & 12,605 & 17,796 & 7,067 \\
\hline
\end{tabular}

Source: Dutch National Agricultural Census $(C B S, 2017)$, edited by Wageningen Economic Research. 
Table A2.3 The average size in agriculture area and number of animals per farm for three farm types in The Netherlands in 2016 near nature

\begin{tabular}{|c|c|c|c|c|}
\hline Description & $\begin{array}{r}\text { Natura } 2000 \\
<400 \mathrm{~m}\end{array}$ & $\begin{array}{r}\text { Natura } 2000 \\
>400 \mathrm{~m} \text { and } \\
<2,000 \mathrm{~m}\end{array}$ & $\begin{array}{r}\text { Other nature } \\
<400 \mathrm{~m}\end{array}$ & $\begin{array}{r}\text { Other nature } \\
>400 \mathrm{~m} \text { and } \\
<2,000 \mathrm{~m}\end{array}$ \\
\hline - Culture area (ha) & 56 & 54 & 53 & 55 \\
\hline - Dairy cows (number) & 93 & 98 & 96 & 107 \\
\hline - Culture area (ha) & 12 & 12 & 15 & 16 \\
\hline - Finishers (number) & 1,029 & 1,543 & 1,938 & 2,404 \\
\hline - Sows (number) & 244 & 251 & 343 & 285 \\
\hline \multicolumn{5}{|l|}{ Broiler farms/farm } \\
\hline
\end{tabular}

Source: Dutch National Agricultural Census (CBS,2017), edited by Wageningen Economic Research. 


\section{Appendix 3 Emission factors from Dutch Regeling Ammoniak en Veehouderij (RAV)}

Source: http://wetten.overheid.nl/BWBR0013629/2017-04-12

Emissiefactoren voor de berekening van de ammoniakemissie van een dierenverblijf, inclusief de emissie van de mest die in het dierenverblijf aanwezig is.

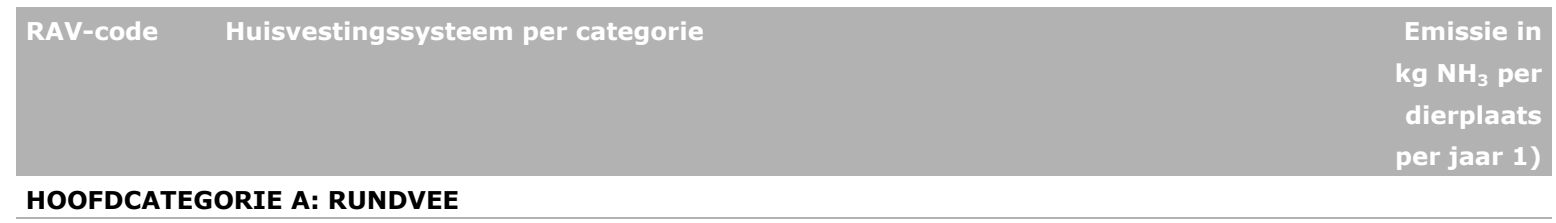

\begin{tabular}{|c|c|c|}
\hline A 1 & diercategorie melk- en kalfkoeien ouder dan 2 jaar & \\
\hline A 1.1 & $\begin{array}{l}\text { grupstal met drijfmest, emitterend mestoppervlak van grup en kelder max. } 1,2 \mathrm{~m}^{2} \text { per } \\
\text { koe(Groen Label BB 93.06.009) }\end{array}$ & 5,7 \\
\hline A 1.2 & $\begin{array}{l}\text { loopstal met hellende vloer en giergoot of met roostervloer; beide met spoelsysteem(BWL } \\
\text { 2001.28.V1) }\end{array}$ & 10,2 \\
\hline A 1.3 & $\begin{array}{l}\text { loopstal met hellende vloer en giergoot; max. } 3 \mathrm{~m}^{2} \text { mestbesmeurd oppervlak per koe(Groen } \\
\text { Label BB 93.03.003V1; BB 93.03.003/A 93.04.004V1;BB 93.03.003/B 93.04.005V1; BB } \\
\text { 93.03.003/C 93.04.006V1;BB 93.03.003/D 94.06.020V1) }\end{array}$ & 10,2 \\
\hline A 1.4 & $\begin{array}{l}\text { loopstal met hellende vloer en spoelsysteem; max. 3,75 } \mathrm{m}^{2} \text { mestbesmeurd oppervlak per } \\
\text { koe(Groen Label BB 94.02.015V1) }\end{array}$ & 9,2 \\
\hline A 1.5 & loopstal met sleufvloer en mestschuif(BWL 2010.24.V5) & 11,8 \\
\hline A 1.6 & $\begin{array}{l}\text { ligboxenstal met dichte hellende vloer, met profilering, met snelle gierafvoer met } \\
\text { mestschuif(BWL 2009.11.V4) }\end{array}$ & 11,0 \\
\hline A 1.7 & $\begin{array}{l}\text { ligboxenstal met dichte hellende vloer, met rubbertoplaag, met snelle gierafvoer met } \\
\text { mestschuif(BWL 2009.22.V4) }\end{array}$ & 11,0 \\
\hline A 1.8 & ligboxenstal met sleufvloer met noppen en mestschuif(BWL 2010.14.V4) & 11,8 \\
\hline A 1.9 & $\begin{array}{l}\text { ligboxenstal met roostervloer voorzien van een bolle rubber toplaag en afdichtflappen in de } \\
\text { roosterspleten, met mestschuif(BWL 2010.30.V4) }{ }^{28}\end{array}$ & 6,0 \\
\hline A 1.10 & $\begin{array}{l}\text { ligboxenstal met roostervloer voorzien van een bolle rubber toplaag, met mestschuif(BWL } \\
\text { 2010.31.V4) }\end{array}$ & 7 \\
\hline A 1.11 & $\begin{array}{l}\text { ligboxenstal met geprofileerde vlakke vloer met hellende sleuven, regelmatige mestafstorten } \\
\text { en met een mestschuif(BWL 2010.32.v3) }{ }^{19}\end{array}$ & 11,8 \\
\hline A 1.12 & $\begin{array}{l}\text { ligboxenstal met geprofileerde vlakke vloer met hellende sleuven, regelmatige mestafstorten } \\
\text { en mestschuif(BWL 2010.33.V4) }{ }^{19}\end{array}$ & 12,2 \\
\hline A 1.13 & $\begin{array}{l}\text { ligboxenstal met roostervloer voorzien van cassettes in de roosterspleten en mestschuif(BWL } \\
\text { 2010.34.V6) }\end{array}$ & 7 \\
\hline A 1.14 & $\begin{array}{l}\text { ligboxenstal met geprofileerde vlakke vloer met hellende sleuven, regelmatige mestafstorten } \\
\text { voorzien van afdichtflappen, met mestschuif(BWL 2010.35.V5) }\end{array}$ & 7 \\
\hline A 1.15 & $\begin{array}{l}\text { ligboxenstal met geprofileerde vlakke vloer met hellende sleuven, regelmatige mestafstorten } \\
\text { voorzien van emissiereductiekleppen en met mestschuif(BWL 2010.36.V4) }{ }^{19}\end{array}$ & 10,3 \\
\hline A 1.16 & $\begin{array}{l}\text { ligboxenstal met V-vormige vloer van gietasfalt in combinatie met een gierafvoerbuis en met } \\
\text { mestschuif(BWL 2012.01.V2) }{ }^{19}\end{array}$ & 11,7 \\
\hline A 1.17 & mechanisch geventileerde stal met een chemisch luchtwassysteem(BWL 2012.02.V3) ${ }^{19}$ & 5,1 \\
\hline A 1.18 & $\begin{array}{l}\text { ligboxenstal met V-vormige vloer van geprofileerde vloerelementen in combinatie met een } \\
\text { gierafvoerbuis en met mestschuif(BWL 2012.04.V3) }\end{array}$ & 8 \\
\hline A 1.19 & $\begin{array}{l}\text { ligboxenstal met roostervloer met hellende groeven of hellend gelegd, voorzien van } \\
\text { afdichtkleppen in de roosterspleten en met mestschuif(BWL 2012.05.V2) }{ }^{19}\end{array}$ & 11,0 \\
\hline A 1.20 & $\begin{array}{l}\text { ligboxenstal met vloer voorzien van perforaties en hellende profilering en mestschuif(BWL } \\
\text { 2012.08.V1) }{ }^{19}\end{array}$ & 10,1 \\
\hline
\end{tabular}




\begin{tabular}{|c|c|c|}
\hline RAV-code & Huisvestingssysteem per categorie & $\begin{array}{l}\text { Emissie in } \\
\mathrm{kg} \mathrm{NH}_{3} \text { per } \\
\text { dierplaats } \\
\text { per jaar 1) }\end{array}$ \\
\hline A 1.21 & $\begin{array}{l}\text { ligboxenstal met vlakke vloerplaten met tegelprofiel, hellende sleuven en regelmatige } \\
\text { mestafstorten voorzien van afdichtflappen of -kleppen en mestschuif(BWL 2013.01.V2) }\end{array}$ & 7 \\
\hline A 1.22 & $\begin{array}{l}\text { ligboxenstal met sleufvloer en mestschuif en in de doorsteken, wachtruimte en doorlopen } \\
\text { een roostervloer met bolle rubber toplaag voorzien van afdichtflappen in de } \\
\text { roosterspleten(BWL 2013.03.V1) }\end{array}$ & 11,0 \\
\hline A 1.23 & $\begin{array}{l}\text { ligboxenstal met geprofileerde vloerplaten met sterk hellende langssleuven met } \\
\text { urineafvoergat en hellende dwarsgroeven, aaneengesloten gelegd of gescheiden door } \\
\text { mestafstorten voorzien van emissiereductiekleppen, met mestschuif(BWL 2013.04.V2) }\end{array}$ & 6 \\
\hline A 1.24 & $\begin{array}{l}\text { ligboxenstal met vloer met sterk hellende langssleuven, de vloerplaten aaneengesloten } \\
\text { gelegd of gescheiden door mestafstorten voorzien van afdichtflappen, met mestschuif (BWL } \\
\text { 2013.05.V2) }{ }^{19}\end{array}$ & 9,1 \\
\hline A 1.25 & $\begin{array}{l}\text { ligboxenstal met vlakke vloer, voorzien van geprofileerde rubber matten met een hellend } \\
\text { profiel naar regelmatige mestafstorten voorzien van afdichtflappen, met mestschuif(BWL } \\
\text { 2013.06.V1) }{ }^{19}\end{array}$ & 10,3 \\
\hline A 1.26 & $\begin{array}{l}\text { ligboxenstal met hellende V-vormige vloer, voorzien van geprofileerde rubber matten, met } \\
\text { centrale giergoot en mestschuif(BWL 2013.07.V1) }{ }^{19}\end{array}$ & 9,6 \\
\hline A 1.27 & $\begin{array}{l}\text { ligboxenstal met roostervloer met hellende groeven of hellend gelegd, voorzien van } \\
\text { afdichtkleppen in de roosterspleten, met mestschuif en vernevelsysteem(BWL 2014.02.V1) }{ }^{19}\end{array}$ & 10,3 \\
\hline A 1.28 & $\begin{array}{l}\text { Ligboxenstal met roostervloer, voorzien van rubber matten en composiet nokken met een } \\
\text { hellend profiel, kunststofcassettes met kleppen in de roosterspleten en met mestschuif(BWL } \\
\text { 2015.05) }\end{array}$ & 7,7 \\
\hline A 1.29 & $\begin{array}{l}\text { Ligboxenstal met geprofileerde hellende vloer met holtes voor gieropvang en -afvoer aan de } \\
\text { zijkant en met mestschuif(BWL 2015.06) }{ }^{19}\end{array}$ & 9,9 \\
\hline A 1.100 & overige huisvestingssystemen & 13,0 \\
\hline D 3 & $\begin{array}{l}\text { diercategorie vleesvarkens, opfokberen van circa } 25 \mathrm{~kg} \text { tot } 7 \text { maanden, } \\
\text { opfokzeugen van circa } 25 \mathrm{~kg} \text { tot eerste dekking }\end{array}$ & \\
\hline D 3.1 & volledig roostervloer (BWL 2001.21.V1) & 4,5 \\
\hline D 3.2 & gedeeltelijk roostervloer & \\
\hline D 3.2 .1 & gehele dierplaats onderkelderd zonder stankafsluiter (BWL 2001.23.V1) ${ }^{5}$ & 4,5 \\
\hline D 3.2 .2 & $\begin{array}{l}\text { mestopvang in en spoelen met } \mathrm{NH}_{3} \text {-arme vloeistof (inclusief aanzuren) } \\
\text { (Groen Label BB 93.06.010V1; BB 93.11.011; BB 93.11.011/A 95.04.024) (BWL } \\
\text { 2001.24.V1) }\end{array}$ & 1,6 \\
\hline D 3.2 .3 & koeldeksysteem met metalen driekantroostervloer (170\% koeloppervlak) (BWL 2001.25.V2) ${ }^{5}$ & 1,7 \\
\hline D 3.2 .4 & $\begin{array}{l}\text { mestopvang in met formaldehyde behandelde mestvloeistof in combinatie met metalen } \\
\text { driekantroostervloer(Groen Label BB 95.02.025V2) }\end{array}$ & 1,0 \\
\hline D 3.2 .5 & $\begin{array}{l}\text { mestopvang in water in combinatie met metalen driekant roostervloer(Groen Label BB } \\
95.10 .029 \mathrm{~V} 3)^{5}\end{array}$ & 1,3 \\
\hline D 3.2 .6 & koeldeksysteem (200\% koeloppervlak) & \\
\hline D 3.2.6.1 & met metalen roostervloer & \\
\hline D 3.2.6.1.1 & emitterend mestoppervlak maximaal $0,8 \mathrm{~m}^{2}$ per varken $(B W L 2010.19 . \mathrm{V} 2)^{5}$ & 1,5 \\
\hline D 3.2.6.1.2 & emitterend mestoppervlak maximaal $0,5 \mathrm{~m}^{2}(B W L 2004.08 . \mathrm{V} 2)^{5}$ & 1,2 \\
\hline D 3.2.6.2 & met roostervloer anders dan metaal & \\
\hline D 3.2.6.2.1 & emitterend mestoppervlak maximaal 0,6 $\mathrm{m}^{2}$ per varken $(B W L 2010.20 . \mathrm{V} 2)^{5}$ & 1,6 \\
\hline D 3.2.6.2.2 & $\begin{array}{l}\text { emitterend mestoppervlak groter dan } 0,6 \mathrm{~m}^{2} \text {, doch kleiner dan } 0,8 \mathrm{~m}^{2} \text { per varken( } B W L \\
\text { 2001.01.V2) }\end{array}$ & 2,4 \\
\hline D 3.2 .7 & mestkelders met (water- en) mestkanaal; mestkanaal met schuine putwand & \\
\hline D 3.2.7.1 & met metalen driekantroosters op het mestkanaal & \\
\hline D 3.2.7.1.1 & $\begin{array}{l}\text { emitterend mestoppervlak maximaal } 0,18 \mathrm{~m}^{2} \text { per varken(Groen Label BB 97.07.056/A } \\
\text { 97.11.059V2) }(B W L 2004.03 . \mathrm{V} 2)^{5}\end{array}$ & 1,0 \\
\hline D 3.2.7.1.2 & $\begin{array}{l}\text { emitterend mestoppervlak groter dan } 0,18 \mathrm{~m}^{2} \text {, maar kleiner dan } 0,27 \mathrm{~m}^{2} \text { per varken(Groen } \\
\text { Label BB 97.07.056/A 97.11.059V2) (BWL 2004.04.V2) }{ }^{5}\end{array}$ & 1,4 \\
\hline D 3.2.7.2 & met roosters anders dan metalen driekant op het mestkanaal & \\
\hline D 3.2.7.2.1 & emitterend mestoppervlak maximaal $0,18 \mathrm{~m}^{2}$ per varken $(B W L 2004.05 . \mathrm{V} 4)^{5}$ & 1,5 \\
\hline D 3.2.7.2.2 & $\begin{array}{l}\text { emitterend mestoppervlak groter dan } 0,18 \mathrm{~m}^{2} \text {, maar kleiner dan } 0,27 \mathrm{~m}^{2} \text { per varken( } B W L \\
2010.10 . \mathrm{V} 3)^{5}\end{array}$ & 1,9 \\
\hline
\end{tabular}


2007.03.V6; BWL 2008.01.V4; BWL 2008.02.V4; BWL 2008.03.V4; BWL 2008.04.V4; BWL 2008.05.V4; BWL 2008.12.V4; BWL 2009.13. V4; BWL 2009.20.V3; BWL 2009.21.V2; BWL 2010.27.V4; BWL 2010.28.V4; BWL 2011.11.V3; BWL 2011.12.V3; BWL 2013.02.V2; BWL 2015.04.V2) ${ }^{3}$

D 3.2.9 chemisch luchtwassysteem 70\% emissiereductie (BWL 2004.02.V4; BWL 2005.01.V6; BWL 2006.04.V3; BWL 2006.05.V4; BWL 2008.06.V5; BWL 2008.07.V3; BWL 2009.01.V4; BWL 2010.25.V2; BWL 2011.14.V3; BWL 2014.01.V2) ${ }^{3,5}$

D 3.2.10 bollevloerhok met betonnen morsrooster en metalen driekantrooster

D 3.2.10.1 emitterend mestoppervlak maximaal 0,22 $\mathrm{m}^{2}$ per varken(BWL 2001.27.V3)

D 3.2.10.2 emitterend mestoppervlak maximaal 0,33 $\mathrm{m}^{2}$ per varken(BWL 2001.27.V3) hok met gescheiden mestkanalen (BWL 2001.03.V1)

D 3.2.11

D 3.2.12 spoelgotensysteem met metalen driekantroosters(Groen Label BB 98.10.064) ${ }^{5}$

D 3.2.13 spoelgotensysteem met roosters(Groen Label BB 98.10.065; BB 98.10.065/A 99.11.079V1) ${ }^{5}$ chemisch luchtwassysteem 95\% emissiereductie(BWL 2007.05.V5; BWL 2008.08.V4; BWL 2008.09.V4; BWL 2010.26.V2) 3,5

D 3.2.15 luchtwassystemen anders dan biologisch of chemisch

D 3.2.15.1 gecombineerd luchtwassysteem 85\% emissiereductie met chemische wasser (lamellenfilter) $\quad 0,45$ en waterwasser(BWL 2006.14.V5) ${ }^{3,5}$

D 3.2.15.2 gecombineerd luchtwassysteem 70\% emissiereductie met waterwasser, chemische wasser en $\quad 0,9$ biofilter(BWL 2006.15.V6) ${ }^{3,5}$

D 3.2.15.3 gecombineerd luchtwassysteem $85 \%$ emissiereductie met waterwasser, chemische wasser en $\quad 0,45$ biofilter(BWL 2007.01.V6) ${ }^{3,5}$

D 3.2.15.4 gecombineerd luchtwassysteem $85 \%$ emissiereductie met watergordijn en biologische 0,45 wasser(BWL 2007.02.V4; BWL 2009.12.V2; BWL 2010.02.V4) ${ }^{3,5}$

D 3.2.15.5 gecombineerd luchtwassysteem 85\% emissiereductie met waterwasser, biologische wasser $\quad 0,45$ en geurverwijderingssectie(BWL 2011.07.V3) ${ }^{3,5}$

D 3.2.15.6 gecombineerd luchtwassysteem $90 \%$ emissiereductie met een biologische en een chemische $\quad 0,3$ wasser en een biofilter(BWL 2011.08.V3) ${ }^{3,5}$

D 3.2.16 gescheiden afvoer van mest en urine door middel van een $V$-vormige mestband in het 1,1 mestkanaal met metalen driekant roosters op het mestkanaal(BWL 2008.11.V1) ${ }^{5}$

D 3.2.17 biologisch luchtwassysteem $85 \%$ emissiereductie(BWL 2012.07.V3) ${ }^{3}$

D 3.2.18 chemisch luchtwassysteem 90\% emissiereductie(BWL 2013.08.V1) ${ }^{3} \quad 0.3$

D 3.3 scharrel vleesvarkens

D 3.3.1 beddenstal met maximaal $0,14 \mathrm{~m}^{2}$ emitterend mestoppervlak per dier tot $50 \mathrm{~kg}$ levend gewicht en met maximaal $0,29 \mathrm{~m}^{2}$ emitterend mestoppervlak per dier vanaf $50 \mathrm{~kg}$ levend gewicht(BWL 2001.30 $)^{5}$

D 3.3.2 overige huisvestingssystemen scharrel vleesvarkens ${ }^{5} \quad 3,0$

$\begin{array}{ll}\text { D } 3.100 \quad \text { overige huisvestingssystemen } & 3,0\end{array}$

\begin{tabular}{|c|c|c|}
\hline E 5 & diercategorie vleeskuikens & \\
\hline \multirow[t]{2}{*}{ E 5.1} & zwevende vloer met strooiseldroging(Groen Label BB 93.03.002; BB 93.03.002/A & 0,005 \\
\hline & 94.04.017V1; BB 93.03.002/B 96.04.034; BB 93.03.002/C 96.10.048) & \\
\hline E 5.2 & $\begin{array}{l}\text { geperforeerde vloer met strooiseldroging(Groen Label BB 94.04.016; BB 94.04.016/A } \\
96.10 .047 \text { ) }\end{array}$ & 0,014 \\
\hline E 5.3 & etagesysteem met volledige roostervloer en mestbandbeluchting(Groen Label BB 97.07.057) & 0,005 \\
\hline E 5.4 & $\begin{array}{l}\text { chemisch luchtwassysteem 90\% emissiereductie(BWL 2008.08.V4; BWL 2007.05.V5; BWL } \\
\text { 2013.08.V1) }\end{array}$ & 0,008 \\
\hline E 5.5 & grondhuisvesting met vloerverwarming en vloerkoeling(BWL 2001.11.V2) ${ }^{11}$ & 0,045 \\
\hline E 5.6 & stal met mixluchtventilatie(BWL 2005.10.V4) ${ }^{11}$ & 0,037 \\
\hline E 5.7 & $\begin{array}{l}\text { biologisch luchtwassysteem 70\% emissiereductie (BWL 2006.02.V4; BWL 2007.03.V6; BWL } \\
\text { 2009.13.V4; BWL 2010.27.V4; BWL 2010.28.V4; BWL 2011.11.V3; BWL 2013.02.V2; BWL } \\
\text { 2015.04.V2) }\end{array}$ & 0,024 \\
\hline E 5.8 & etagesysteem met mestband en strooiseldroging $(B W L 2006.13)^{6}$ & 0,020 \\
\hline E 5.9 & uitbroeden eieren en opfokken vleeskuikens met aparte vervolghuisvesting & \\
\hline E 5.9.1 & uitbroeden eieren en opfokken vleeskuikens in etages met vervolghuisvesting & \\
\hline
\end{tabular}




\begin{tabular}{|c|c|c|}
\hline RAV-code & Huisvestingssysteem per categorie & $\begin{array}{l}\text { Emissie in } \\
\text { kg NH} \\
\text { dierplaats } \\
\text { per jaar 1) }\end{array}$ \\
\hline E 5.9.1.1 & $\begin{array}{l}\text { uitbroeden eieren en opfokken vleeskuikens tot } 13 \text { dagen in stal met etages en } \\
\text { vervolghuisvesting }\end{array}$ & \\
\hline E 5.9.1.1.1 & $\begin{array}{l}\text { uitbroeden eieren en opfokken vleeskuikens tot } 13 \text { dagen in stal met etages en } \\
\text { vervolghuisvesting in E } 5.5 \text { (grondhuisvesting met vloerverwarming en vloerkoeling)(BWL } \\
2009.02)^{12}\end{array}$ & 0,040 \\
\hline E 5.9.1.1.2 & $\begin{array}{l}\text { uitbroeden eieren en opfokken vleeskuikens tot } 13 \text { dagen in stal met etages en } \\
\text { vervolghuisvesting in E } 5.6 \text { (stal met mixluchtventilatie)(BWL 2009.03) }{ }^{12}\end{array}$ & 0,033 \\
\hline E 5.9.1.1.3 & $\begin{array}{l}\text { uitbroeden eieren en opfokken vleeskuikens tot } 13 \text { dagen in stal met etages en } \\
\text { vervolghuisvesting in E } 5.8 \text { (etagesysteem met mestband en strooiseldroging)(BWL 2009.04) } \\
6,12\end{array}$ & 0,018 \\
\hline E 5.9.1.1.4 & $\begin{array}{l}\text { uitbroeden eieren en opfokken vleeskuikens tot } 13 \text { dagen in stal met etages en } \\
\text { vervolghuisvesting in E } 5.10 \text { (stal met verwarmingssysteem met warmteheaters en } \\
\text { ventilatoren)(BWL 2009.15) }{ }^{12}\end{array}$ & 0,031 \\
\hline E 5.9.1.1.100 & $\begin{array}{l}\text { uitbroeden eieren en opfokken vleeskuikens tot } 13 \text { dagen in stal met etages en } \\
\text { vervolghuisvesting in E } 5.100 \text { (overige huisvestingsystemen)(BWL 2009.08) }{ }^{12}\end{array}$ & 0,070 \\
\hline E 5.9.1.2 & $\begin{array}{l}\text { uitbroeden eieren en opfokken vleeskuikens tot } 19 \text { dagen in stal met etages en } \\
\text { vervolghuisvesting }\end{array}$ & \\
\hline E 5.9.1.2.1 & $\begin{array}{l}\text { uitbroeden eieren en opfokken vleeskuikens tot } 19 \text { dagen in stal met etages en } \\
\text { vervolghuisvesting in E } 5.5 \text { (grondhuisvesting met vloerverwarming en vloerkoeling)(BWL } \\
\text { 2009.05) }{ }^{13}\end{array}$ & 0,038 \\
\hline E 5.9.1.2.2 & $\begin{array}{l}\text { uitbroeden eieren en opfokken vleeskuikens tot } 19 \text { dagen in stal met etages en } \\
\text { vervolghuisvesting in E } 5.6 \text { (stal met mixluchtventilatie)(BWL 2009.06) }{ }^{13}\end{array}$ & 0,033 \\
\hline E 5.9.1.2.3 & $\begin{array}{l}\text { uitbroeden eieren en opfokken vleeskuikens tot } 19 \text { dagen in stal met etages en } \\
\text { vervolghuisvesting in E } 5.8 \text { (etagesysteem met mestband en strooiseldroging)(BWL 2009.07) } \\
6,13\end{array}$ & 0,015 \\
\hline E 5.9.1.2.4 & $\begin{array}{l}\text { uitbroeden eieren en opfokken vleeskuikens tot } 19 \text { dagen in stal met etages en } \\
\text { vervolghuisvesting in E } 5.10 \text { (stal met verwarmingssysteem met warmteheaters en } \\
\text { ventilatoren)(BWL 2009.16) }\end{array}$ & 0,030 \\
\hline E 5.9.1.2.100 & $\begin{array}{l}\text { uitbroeden eieren en opfokken vleeskuikens tot } 19 \text { dagen in stal met etages en } \\
\text { vervolghuisvesting in E } 5.100 \text { (overige huisvestingsystemen)(BWL 2009.09) }{ }^{13}\end{array}$ & 0,060 \\
\hline E 5.10 & stal met verwarmingssysteem met warmteheaters en ventilatoren(BWL 2009.14.V5) ${ }^{11}$ & 0,035 \\
\hline E 5.11 & $\begin{array}{l}\text { stal met luchtmengsysteem voor droging strooisellaag in combinatie met een } \\
\text { warmtewisselaar(BWL 2010.13.V5) }{ }^{11}\end{array}$ & 0,021 \\
\hline E 5.12 & biofilter $70 \%$ emissiereductie(BWL 2011.03.V1) ${ }^{3}$ & 0,024 \\
\hline E 5.13 & $\begin{array}{l}\text { chemisch luchtwassysteem 70\% emissiereductie (BWL 2005.01.V6; BWL 2008.06.V5; BWL } \\
\text { 2014.01.V2) }\end{array}$ & 0,024 \\
\hline E 5.14 & $\begin{array}{l}\text { stal met warmteheaters met luchtmengsysteem voor droging strooisellaag(BWL 2011.13.V4) } \\
11\end{array}$ & 0,035 \\
\hline E 5.15 & Stal met buizenverwarming (BWL 2017.01) & 0,012 \\
\hline E 5.100 & overige huisvestingssystemen & 0,080 \\
\hline
\end{tabular}

1) For dairy cattle with more than 720 grazing hours the ammonia emission from stables is $5 \%$ lower. 
Wageningen Economic Research P.O. Box 29703

2502 LS The Hague

The Netherlands

$\mathrm{T}+31(0) 703358330$

E communications.ssg@wur.nl

www.wur.eu/economic-research

Wageningen Economic Research REPORT

2018-010
The mission of Wageningen University and Research is "To explore the potential of nature to improve the quality of life". Under the banner Wageningen University \& Research, Wageningen University and the specialised research institutes of the Wageningen Research Foundation have joined forces in contributing to finding solutions to important questions in the domain of healthy food and living environment. With its roughly 30 branches, 5,000 employees and 10,000 students, Wageningen University \& Research is one of the leading organisations in its domain. The unique Wageningen approach lies in its integrated approach to issues and the collaboration between different disciplines.

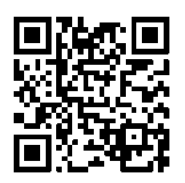





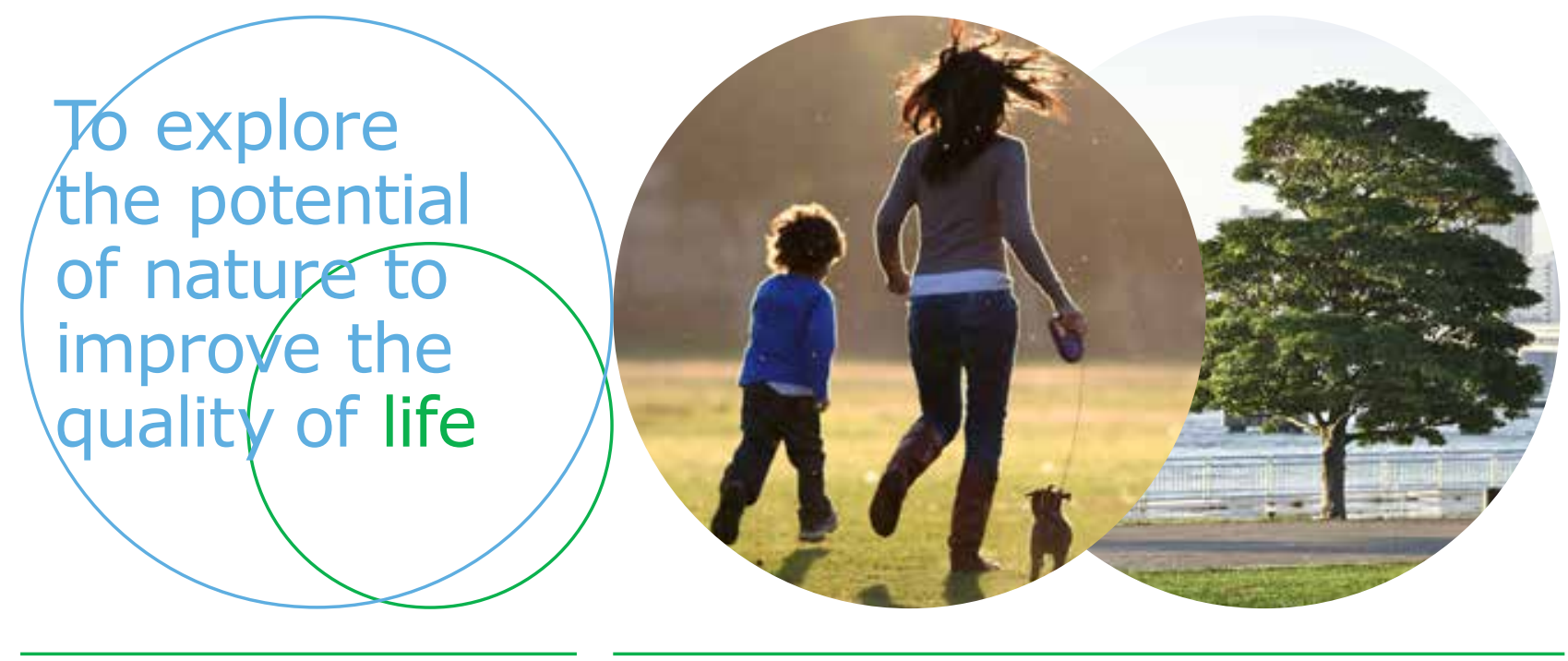

Wageningen Economic Research Postbus 29703

2502 LS Den Haag

E communications.ssg@wur.nl

$\mathrm{T}+31(0) 703358330$

www.wur.nl/economic-research

Report 2018-010

ISBN 978-94-6343-845-2
De missie van Wageningen University \& Research is 'To explore the potential of nature to improve the quality of life'. Binnen Wageningen University \& Research bundelen Wageningen University en gespecialiseerde onderzoeksinstituten van Stichting Wageningen Research hun krachten om bij te dragen aan de oplossing van belangrijke vragen in het domein van gezonde voeding en leefomgeving. Met ongeveer 30 vestigingen, 5.000 medewerkers en 10.000 studenten behoort Wageningen University \& Research wereldwijd tot de aansprekende kennisinstellingen binnen haar domein. De integrale benadering van de vraagstukken en de samenwerking tussen verschillende disciplines vormen het hart van de unieke Wageningen aanpak. 